\title{
An Empirical Study of Impact of EVA Momentum on the Shareholders Value Creation as Compared to Traditional Financial Performance Measures - With Special Reference to the UAE
}

\author{
Dr. Ahmed Magdy Fayed ${ }^{1} \&$ Dr. Suchi Dubey ${ }^{2}$ \\ ${ }^{1}$ University of Atlanta (UOFA), GA, United States \\ ${ }^{2}$ University of Modern Sciences (UMS), Dubai, UAE \\ Correspondence: Dr. Ahmed Magdy Fayed, University of Atlanta (UOFA), GA, United States. Tel: \\ 971-50-482-5058. E-mail: a.m.fayed73@gmail.com
}

Received: February 6, 2016

Accepted: February 22, 2016

Online Published: April 25, 2016

doi:10.5539/ijef.v8n5p23

URL: http://dx.doi.org/10.5539/ijef.v8n5p23

\begin{abstract}
The unawareness of value-based performance measures when allocating investments could lead to destroying value. This paper presents comparison of three groups of performance measures being accounting-traditional measures, market-based measures and value-based measures with special focus on EVA Momentum calculated as ( $\triangle$ EVA / Trailing Sales). The study covers UAE stock exchanges from 2008 to 2013. A methodology is designed to determine the right transformation of panel data then deciding on the appropriate regression technique among Fixed Effects, Random Effects or Pooled OLS model. Advanced modeling techniques as Driscoll-Kraay and Prais-Winsten models are used to examine serial correlation and heteroskedasticity.
\end{abstract}

Keywords: driscoll-kraay, economic value added, eva momentum, hausman test, prais-winsten, wealth creation

\section{Introduction}

\subsection{Introduce the Problem}

A key performance indicator of a business organization should indicate whether the business is successful, or more specifically, is profitable. However, the definition of profit varies depending on the understanding of the profit term itself whether by investors or financial institutions or other stakeholders. While these various parties usually focus their attention on the net profit, EPS, ROI, ROE or other traditional accounting measures, the rational investor would seek an answer, as to whether the business has created real economic profit. The idea behind economic profit aims to create the real value maximization for the shareholders. It represents the value created in excess of the required return to the company's shareholders. Economic profit is not only an indicator of shareholders wealth maximization but rather it also indicates the decision making and performance of the management of the company.

Stewart (1990) introduced the Economic Value Added (EVA@) metric as a measure of economic profit and a driver of shareholder value, and he has set the Market Value Added (MVA) as a measure of value added to shareholders.

EVA could be measured in two ways: first, as net operating profit after tax, or NOPAT, less a capital charge computed by multiplying the firm's total capital by the weighted average cost of capital; and second, as the percentage spread between the return on capital and cost of capital, times the firm's total invested capital. Hence EVA does not begin to count profit until shareholders earn at least the return on capital they could expect to earn elsewhere at the same level of risk. While EVA Momentum is calculated as ( $\triangle$ EVA / Trailing Sales), accordingly EVA Momentum always moves in perfect lockstep with the change in EVA, because the trailing sales denominator is fixed once any period begins (Stewart, 2009).

It is worth noting that EVA computation should be preceded by correcting for accounting distortions, the logical reason for this simply is that true tangible and intangible assets enable the firm it to generate EVA profit, hence EVA will capitalize intangible assets in balance sheet and amortize them over time when accounting standards dictate that the outlays to cultivate intangible assets be expensed as if they have no ongoing value, examples of such expenditures are spending on training, $R \& D$, and brand-building where EVA will capitalize them and make 
them subject to a capital charge on the unamortized balance as similar to plant and equipment. EVA also corrects for distortions in inventory valuation, fixed assets depreciation, off-balance sheet assets and many others (Stewart, 2003), which make EVA eventually reconcilable to the Net Present Value (NPV).

Following this logic, EVA is expected to be a much superior performance measure as compared to traditional measures like Net Profit or EBITDA in that it accounts for the implied cost of capital and also introduces number of rectifications to the accounting reporting that could mislead the assessment of the company's underlying performances even if the financial reporting follow the internationally general accepted accounting standards.

Since its introduction, the EVA shared in the success of reputable corporations by escalating and rationalizing their performances, examples are: Coca-Cola, Briggs and Stratton, Herman Miller, and many others. EVA has the ability to be thoroughly implemented as performance indicator in most of the sub-divisions in an organization and was even utilized in some organizations as a determinate of managers compensation and incentives (Cagle, Smythe, \& Fulmer, 2003).

However, the EVA metric has suffered from certain drawbacks simply because it is reported in the form of an absolute monetary figure which could be vague to many investors and may not fulfill the required role of benchmarking through acting as a size-neutral metric, and hence it was less useful in the financial markets. In practical terms, it was difficult for managers to be asked to maximize a monetary value and basing their compensation upon, rather than linking their compensations to a percentage of improvement. In addition, the EVA earlier model could not straightly answer the question whether if the origins of the period positive or negative performances were coming from profitable growth as developing new profitable products, or from efficiency gains as by capitalizing on the past performances. Accordingly, Stewart (2009) introduced the EVA Momentum as a superior metric over the earlier EVA model and also over the other widely used traditional measures. EVA Momentum is a size-neutral metric since it fulfills the need to report economic profit in the form of percentage which can be drilled down to explore the real economic profit drivers whether generated from Productivity Gains or Profitable Growth or both, with each being able to be drilled down further to reveal the ultimate underlying strengths or weaknesses in the organization at all levels.

\subsection{Significance and Objectives of the Study}

The study aims to provide independent empirical evidence in the UAE on the relative and incremental information content of the value based measures EVA Momentum, EVA, Residual Income as compared to various traditional accounting and market-based measures in the shareholders' wealth creation measured by Total Shareholders Return "TSR". Through this study an attempt is made to narrow the knowledge gap in this regards and reach a conclusion that would either confirm or contradict the claims of Bennett Stewart about the ability of EVA Momentum as a sole metric to predict shareholders' value. The study is considered one of the highly scarce researches focusing on the new metric EVA Momentum and trying to identify if it better explains the stock performances as compared to other performance measures. In order to achieve these targets, a thorough relative and incremental information content analysis is undertaken. A significant aim of the study is to add valuable contribution to the investment evaluation process in the UAE and hence contribute to better market efficiencies and better rationalization in the allocation of capital through answering the following two primary questions:

1) Does the EVA Momentum possess superior ability in affecting the Investment Decision in the UAE stock market as compared to accounting and market-based performance measures?

2) Could the EVA Momentum be considered a superior metric in explaining the variance in shareholders' value creation when combined with other value-based measures, traditional accounting measures, or market-based measures?

\subsection{Research Objectives}

1) EVA Momentum as value-based performance measure has superior relative information content in the Total Shareholders Return "TSR", as compared to either of traditional accounting measures, market-based measures or other value-based measures.

2) EVA Momentum provides higher incremental information content than other performance measures in explaining the Total Shareholders Return "TSR" when combined with either of other value-based measures, traditional accounting measures, or market-based measures.

\subsection{Literature Review}

A number of researches have studied the relative and incremental content of independent variables. The two information content types provide different insights; the relative information content helps selecting a single best 
performance measure among other competing performance measures in explaining variance in dependent variable. While incremental information content helps deciding whether to employ more than one performance measure in the analysis and this could be done by pairing the values of two independent variables (or their change), and observe which variable provides the highest incremental information content leading to improving the explanatory power of another performance measure when combined.

\subsubsection{Traditional Financial Measures as Predictors of Shareholders Value}

Collins, Maydew, and Weiss (1997) researched the value relevance across industries in the U.S. market in the period between 1953 and 1993 resulting in 115,154 firm-years, the independent variables were the earnings and the book value of equity. They concluded that the combined value-relevance of earnings and book value has not declined over 40 years, however the incremental value relevance of earnings has declined being offset by an increase in the value relevance of book value over the period, and that much of the shift in value-relevance from earnings to book values was attributable to the increasing significance of one-time items in addition to the increasing frequency of negative earnings and changes in average firm size and intangibles intensity across time.

The research of Collins et al. was extended by Keener (2011) through applying the same model over the years 1982 to 2001 in the US over a sample of 98,284 firm-years. The study concluded that earnings and book value together explain about $41.3 \%$ of the variation in stock prices while Collins et al. (1997) found that earnings and book value mutually explained about $54 \%$ of the variation in stock price. The overall conclusion was that the mutual ability of earnings and book value have not declined over all these decades and still explain significant content of the value creation.

Ben Ayed and Abaoub (2006) studied the value relevance of accounting earnings, operating earnings, cash flow from operations, earnings from ordinary activity in the stock returns over 43 firms in the Tunisian market during the period between 1997 and 2004, the results showed that operating income, income before taxes, special items and income taxes were value relevant for firm valuation while cash flow from operations and accruals were not value relevant.

Esterhuyse (2011) concluded that assets turnover was not a driver of shareholder value except for one company amongst eight South African listed manufacturing companies over ten years between 2001 and 2010.

Glezakos et al. (2012) examined empirically the impact of earnings and book value in the formulation of stock prices on a sample of 38 companies listed in the Athens Stock Market in the period between the 1996 and 2008, the independent variables were the logarithm of each of EPS and Book Value per Share while the dependent variable was the logarithm of annual stock returns. The resulting evidence suggested that the joint explanatory power of the above parameters in the formation of stock prices increased over time. However, the impact of earnings was diminishing as compared to the book value.

Pouraghajan and Emamgholipourarchi (2012) tested a sample of 400 firm-years among Companies Listed in the Tehran Stock Exchange during the years 2006 to 2010 to examine the impact of working capital management on profitability and Market evaluation of the companies, the variables used to measure the profitability of companies were return on assets ratio and return on invested capital ratio, variable of Tobin $\mathrm{Q}$ ratio was used to measure the market value of companies, while variables of cash conversion cycle, current ratio, current assets to total assets ratio, current liabilities to total assets ratio and total debt to total assets ratio were used as working capital management criteria. The results of the research indicated significant relationship between the working capital management and profitability criteria of company but no significant relationship with the criterion of market value of company.

\subsubsection{EVA as Predictor of Shareholders Value}

Chen and Dodd (1997) studied hundreds of firms in the US market and they suggested based on their research that EVA would likely lead to better stock returns however it was not sufficient as a sole metric and should not completely replace accounting measures.

Biddle et al. (1997) studied the relative and incremental information content of performance measure in terms of their superior association with stock returns and concluded that EVA is significantly related to stock returns but it's explanatory power is lower than each of the residual income and earnings before extraordinary items, these results were confirmed by Chen and Dodd (2001) showing that EVA did not add significant incremental information over residual income.

Worthington and West (2004) studied 110 Australian companies between the years 1992 and 1998 to examine whether EVA is more highly associated with stock returns as compared to traditional popular accounting-based measures. The independent variables measuring performance included earnings, net cash flow and residual 
income. Relative information content tests revealed stock returns to be more closely associated with EVA than residual income, earnings and net cash flow, respectively. An analysis of the components of EVA confirmed that the accounting adjustments was an EVA component which provided the highest explanation of stock returns followed by net cash flow, accruals, after-tax interest and capital charge.

Woo Gon Kim (2006) studied which of EVA or traditional accounting measures is considered the better predictor of Market Value of US Hospitality Companies. The study was run on 623 firm-year observations in the US between 1995 and 2001 and concluded that earnings were more useful than cash flow in explaining the market value of hospitality firm while EVA had very little explanatory power. Incremental information content test showed that EVA generates only a marginal contribution to information content beyond earnings and cash flow.

Forker and Powell (2008) studied large number of companies in US and UK, the US sample covered a period of 16 years (1986 to 2001) while the UK sample covered a period of 12 years (1990 to 2001). Each dataset contained up to 11 variables, including: market value added, EVA, net operating profit after tax, weighted average cost of capital, ending operating capital. The datasets were supplemented by conventional accounting metrics for both the US and UK which included GAAP earnings, residual income, cash flows and other mandated metrics in the US and UK. They concluded that EVA did not outperform residual income metrics, and no conclusions were drawn about the relative ability of economic value measures to predict tock returns.

Visaltanachoti et al. (2008) compared the ability of EVA information content in explaining 90 sector returns in the US market as compared to cash flow from operation (CFO), earnings before interests and tax (EBIT), and residual income (RI). The study employed the data of 90 sectors in the US between the years 2003 and 2005 and decomposed EVA into it's four components: operating cash flows, operating accruals, after-tax interest expense, and capital charge, and examined which of EVA components contributes the most to the association of EVA with sector returns. The relative information test showed that EBIT better explained the variation in the sector returns being reporting higher R-squared than RI, CFO or EVA. While investigation on which components of EVA contribute most toward the association of EVA with sector returns showed that operating accruals and operating cash flows provide information content beyond that provided by components considered unique to EVA such as capital charge.

A research by Maditinos et al. (2009) examined whether EVA or traditional accounting-based measures were more strongly associated with stock returns. The research studied 163 companies in the Athens Stock Exchange (ASE) in the period between 1992 and 2001. The independent variables were EPS, ROI, ROE, EVA and SVA, where the R squared was the basis of comparison. The dependent variable was the stock returns which did not include dividends though adjusted for capital splits and stock dividends. Relative information content tests revealed that stock returns were more closely associated with EPS followed by EVA. While incremental information content tests suggested that EVA added considerable explanatory power to EPS.

Arabsalehi and Mahmoodi (2012) investigated 115 Iranian listed companies in the emerging Tehran stock exchange (TSE) between 2001 and 2008, the sample excluded financial companies and banks and also excluded companies with no active trading being defined as three months without transactions. The dependent variable was the annual stock returns. The study focused firstly on testing the relative information content of 9 independent variables where 5 represented traditional accounting measures being EPS, ROE, ROA, ROS and CFO while the rest 4 represented value-based measures being EVA, REVA, SVA and MVA. The test for relative information content showed that accounting-based measures dominated value-based measures and that ROA and ROE are more associated with stock returns than other measures. The finding of ROA being superior to other measures was consistent with Wirawan (2011) and Dodd and Chen (1997). Secondly, the examination of incremental information content showed that combining EVA and ROA has improved the explanatory power of the ROA.

Parvaei and Farhadi (2013) examined performance measures that better explain and predict the firm's performance. The research studied 80 Iranian listed companies in the emerging Tehran stock exchange (TSE) in the period between 2005 and 2009, the sample excluded financial companies and banks and also excluded companies with no active trading being defined as two months without transactions. The dependent variable was the annual stock returns as acquired from the TSE. The results concluded that EVA is the best measure for evaluating the performance of firm among other measures.

\subsubsection{EVA Adopters}

Some studies have been undertaken on companies which adopt the EVA as performance measure in the decision making process and incentive plans of executives. Kleiman (1999) has researched the relationship between EVA and shareholders' wealth over a sample of selected 71 companies which had adopted EVA between the years 
1987 to 1996. The selection criteria included search of the Chairman's Letter and Management Discussion and Analysis on "EVA", and the statistically significant results showed that EVA companies earned a cumulative excess return of $28.8 \%$ over the subsequent four years, or $\$ 124$ billion of extra shareholder wealth over the median industry competitor. The EVA companies showed better operating margins mainly attributable to the efficient use of assets, and also showed better financial ratios and superior share market performance in consistency with EVA improvements. The findings of Kleiman were consistent with empirical researches by Stern Stewart (as reported in their website) which referred to Kleiman study finding too.

A controversial research by Hogan and Lewis (1999) studying 51 EVA-adopter companies during the years 1988-1994 has found that the performance of the sample set of companies was not statistically different from the matching peer set, however this research was subject to criticisms by different parties including Stern Stewart, arguing that the study had flaws, for example the study assumed that unadjusted accounting numbers allow meaningful comparisons across companies, which is not necessary by default.

Hogan and Lewis convened by another research in (2005) studying 108 companies during the years 1983-1996 and although they reported results showing significant operating and market value improvements following adoption of an economic profit plan, they have however reported that differences in operating performance between adopters and non-adopters were not significantly different.

\subsubsection{EVA Momentum (EVAM) as Predictor of Shareholders Value}

Aziz (2011) investigated the usefulness of the EVA Momentum (EVAM) ratio by determining if Swedish non-real estate, non-financial companies have been either positively or negatively affected by their Corporate Real Estate structure from an EVAM perspective. The study included 43 companies in the period between 2005 and 2009 and reached a conclusion that a negative relationship between EVAM and the ratio of total real estate assets over gross tangible assets at the $10 \%$ real estate intensity interval might exist.

Wirawan (2011) examined the effect of four independent factors EVA, EVA Spread, EVA Momentum and ROA on the stock returns in the Indonesian market between years 2004 and 2008 over 63 listed firms listed and found out that ROA had the most significant effect on stock returns followed by EVA Spread while EVA and EVA Momentum shown insignificant effects on stock returns. The study recommended studying more firms from wider industries and over longer timeframe.

Mahoney (2011) studied number of hypothesis over lodging companies, restaurants and 127 real estate investment companies' data in the US market from 2001 to 2008. The research tested five hypotheses and concluded that there was no statistical difference between lodging EVA Momentum and restaurant EVA Momentum throughout the studied period, the results were not surprising considering similarities between the two industries, however the evidence in the study supported using EVA Momentum as a measurement for comparing companies across industries with similar underlying revenue generation and earnings characteristics.

Nakhaei (2012) examined which of the value-based performance measures being EVA, EVA Momentum and REVA as compared to accounting measures being net profit and operating profit has the greater relationship with the shareholders' wealth being the dependent variable measured by MVA. The research was run on public companies accepted in Main market of Bursa Malaysia between 2001 and 2010. There was no conclusive evidence supporting whether EVA or EVA-related measures are associated with stock performance.

\section{Methodology and Data Design}

\subsection{Overview}

This research applied pooled panel data regression analysis techniques over 43 publicly traded companies in the UAE stock market during the period from 2008 to 2013. The research examines whether EVA Momentum® provides superior association with shareholders total return as compared to other two value-based measures EVA® and Residual Income, and as compared to traditional accounting and market-based performance measures. In testing the hypotheses, the following methodology has been followed:

1) Choosing the appropriate transformation of data to ensure stationarity after testing the panel data for existence of unit root,

2) Applying statistical tests including serial correlation and Heteroskedasticity tests to select the appropriate model that best fits the panel data,

3) Applying multicollinearity testing to filter the independent variables after considering the variables with the most explanatory relative information content, 
4) Reaching the final set of uncorrelated independent variables and examining their relative information content in the total shareholders return through simple linear regression models,

5) Examining the incremental information content through multiple linear regression models by regressing each pair of independent variables on the total shareholders return.

6) Applying statistical tests to select the appropriate regression technique comparing Fixed Effects, Random effects and Pooled OLS models then followed by running Driscoll-Kraay and Prais-Winsten models.

The analysis methodology can be demonstrated by the following diagram:

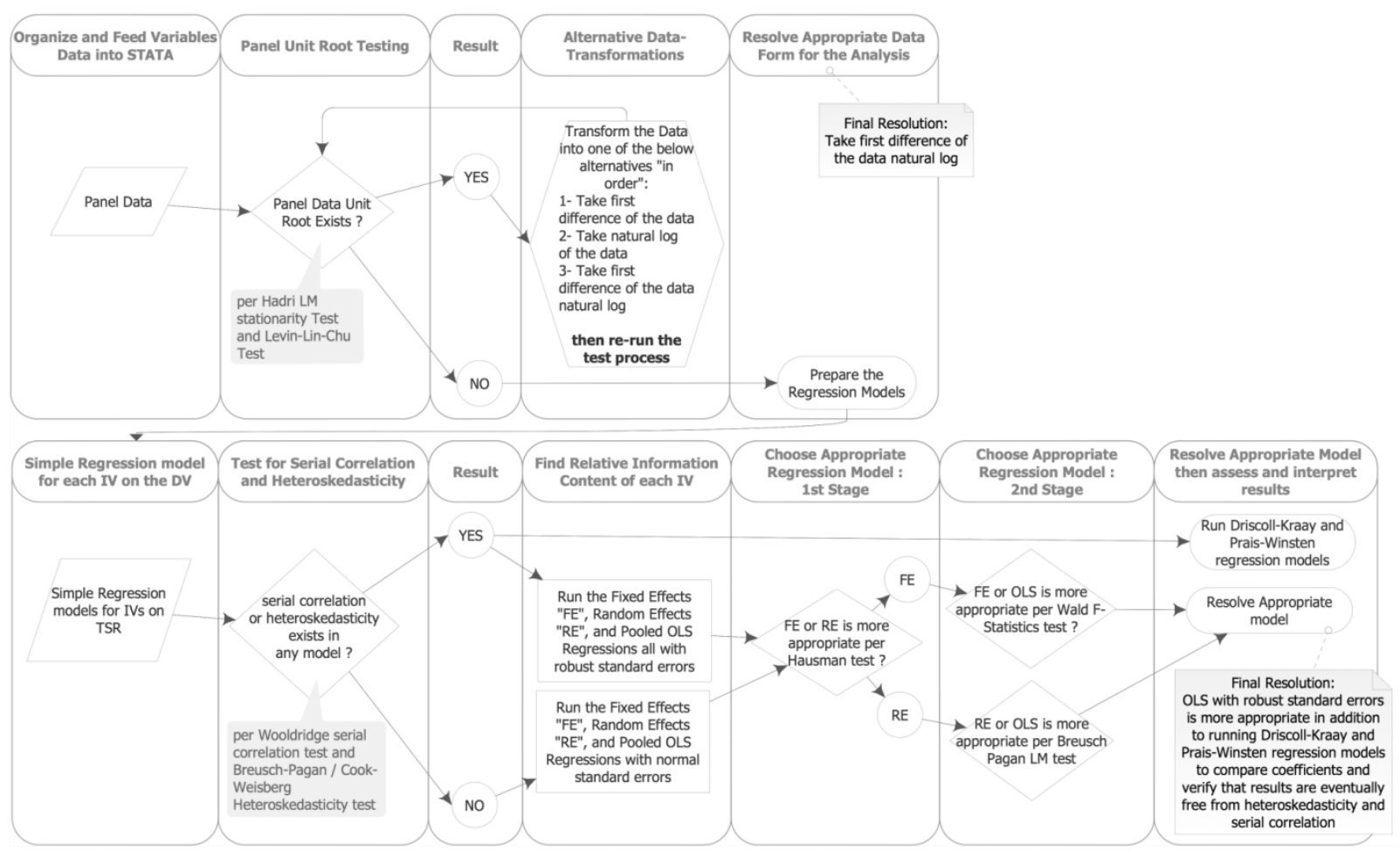

\subsection{Research Sample}

The sample consisted of the listed companies in the DFM and ADX stock markets from 2008-2013 on annual basis after meeting the following criteria for each company:

1- Availability of all six years data with no break in the time-series span

2- Each stock was actively traded in all years

3- Non-insurance company

4- The company exists and operates in the UAE

\subsection{Research Variables and Data Collection}

\subsubsection{Dependent Variable}

The dependent variable is Total Shareholders' Return "TSR" being proxy of shareholders' value and is calculated as [(stock price end of year - stock price beginning of year + dividends) / stock price beginning of year].

The dependent variable data were collected from Zawya-Thomson Reuters database, and each of the DFM and ADX official websites.

\subsubsection{Independent Variables}

The research explores wide number of independent variables representing accounting, market-based and value-based performance measures in order to examine their relative and incremental content in the dependent 
variable over the horizon from 2008-2013.

The following three lists present the initial set of performance measures representing the independent variables prepared in the form of annual percentage change (where " $\mathrm{t}$ " in formulas below represents the financial year):

The following accounting traditional performance measures were studied:

1) Ratio of net book value divided by total assets "BV_D_AS" calculated as net book value in year $t$ "BV" divided by assets in year t "AS,"

2) Return on sales "ROS" calculated as Returns $s_{t} /$ Revenues $_{t}$

3) Net book value "BV"

4) Net book value per outstanding shares "BVPS" calculated as $B V_{t} /$ Outstanding number of shares end of year $\mathrm{t}$

5) Return on average total assets "ROAv" calculated as Returns $t_{t} /\left(\left(\mathrm{AS}_{\mathrm{t}+} \mathrm{AS}_{\mathrm{t}-1}\right) / 2\right)$

6) Return on average net equity "ROEv" calculated as Returns $s_{t} /\left(\left(\mathrm{BV}_{\mathrm{t}+} \mathrm{BV}_{\mathrm{t}-1}\right) / 2\right)$

7) Net profit "NP"

8) Operating margin "OPMGN" calculated as Operating Profits $\mathrm{t}_{\mathrm{t}}$ Revenues $_{\mathrm{t}}$

9) Free cash flow margin "FCF_MGN" calculated as Free Cash Flow $/$ Revenues $_{t}$

10) Free cash flow "FCF"

11) Earnings per share "EPS" calculated as Returns $s_{t}$ / Outstanding number of shares end of year $t$

The following market-based traditional performance measures were studied:

1) Price-Earnings ratio "P_E" being stock market price divided by earnings per share

2) Price to book ratio "P_B" being stock market price divided by book value per share

3) Price to revenues ratio "P_R" being stock market price divided by revenues per share

The following value-based performance measures were studied:

1) Residual income "Res_In" calculated as Operating Profits $s_{t}$ - (Cost of Capital $_{t} X$ Operating Assets $\left.t_{t-1}\right)$

2) Economic value added "EVA" calculated as net operating profit after tax less cost of capital multiplied by the sum of equity and debt

3) Economic value added margin "EVA_MGN" calculated as $\mathrm{EVA}_{t} /$ Revenues $_{t}$

4) EVA Momentum "EVAM" calculated as the annual change in EVA divided by prior period sales

The independent variables data were collected from Zawya-Thomson Reuters database, except for the EVA®, EVA Momentum ${ }^{\circledR}$, and cost of capital which were collected from evaDimensions database.

The initial regression model before eliminations was constructed as follows:

$$
\begin{gathered}
T S R_{i t}=b_{0}+b_{1} B V_{-} D_{-} A S_{i t}+b_{2} R O S_{i t}+b_{3} B V_{i t}+b_{4} B V P S_{i t}+b_{5} R O A v_{i t}+b_{6} R O E v_{i t}+b_{7} N P_{i t}+b_{8} O P M G N_{i t}+ \\
b_{9} F C F_{-} M G N_{i t}+b_{10} F C F_{i t}+b_{11} E P S_{i t}+b_{12} P_{-} E_{i t}+b_{13} P_{-} B_{i t}+b_{14} P_{-} R_{i t}+b_{15} R_{2} I_{-} n_{i t}+b_{16} E V A_{i t}+ \\
b_{17} E V E_{-} M G N_{i t}+b_{18} E V A M_{i t}+e_{i t}
\end{gathered}
$$

The independent variables as shown above were elected to study their relative information content in the dependent variable being the total shareholders' return, this resulted in running 18 simple linear regression models using the five regression techniques examined being fixed effects regression, random effect regressions, pooled OLS regression, Driscoll-Kraay regression and Prais-Winsten regression, as found in Appendix 1.

However, a process of elimination of independent variables was followed to avoid multicollinearity, and where the variables with the highest relative information content were retained, while the variables generating lower information content and high correlation coefficient were eliminated. The relevant information content of the shortlisted independent variables and correlation coefficients matrix along with the summary of eliminations and reasons are found in Appendix 2, and hence resulting in the below shortlist of independent variables:

1) Ratio of net book value divided by total assets "BV_D_AS",

2) Return on sales "ROS",

3) Operating margin "OPMGN", 

4) Free cash flow margin "FCF_MGN",
5) Price to book value "P_B",
6) Residual income "Res_In"
7) Economic value added margin "EVA_MGN"
8) EVA Momentum "EVAM"

\subsubsection{Time Horizon for Data Collection}

Following the quarterly reporting by companies of their official results into the stock market, the dependent variable TSR has been collected with three months lag as compared to the independent variables to allow for the information content in the independent variables to influence the TSR after official dissemination of results, hence the TSR was measured from 31-March-2009 up to 31-March-2014, while all independent variables have been collected or measured from 31-December-2008 up to 31-December-2013.

\subsection{Statistical Tool}

The research has relied on Microsoft excel to collate and organize the data within which were then transferred to the STATA software to commence the statistical analysis.

\subsection{Data Transformation}

A thorough testing of data has been followed to ensure data is Stationary following Hadri Lagrange multiplier Stationarity test (Hadri, 2000), and Lev-Lin-Chu test (Levin, 2002). The tests' results have led to running the statistical models using first difference of data after taking the natural log. The following alternatives were initially tested examined in turn and all have showed existence of unit root in some variables:

1) Data as is at level with no log transformation

2) First difference of data with no log transformation

3) Natural log of data at level

\subsection{Regression Analysis Methods}

This research has examined five alternative panel data regression techniques in order to determine the most appropriate model empirically; these are the Fixed Effects, Random Effects, OLS common effects, Driscoll-Kraay and Prais-Winsten regression models.

The research started analyzing the relationship between TSR and each independent variable through simple linear regressions starting by the Fixed Effects regression to control for unique time-invariant differences between the individual stocks such that the estimated coefficients of the fixed-effects models are not biased because of potential omitted time-invariant characteristics of the stocks studied. The Fixed Effects model removes the effect of those time-invariant characteristics from the predictor variables to isolate the independent variables net effect, hence the Fixed Effects model would be suitable when each stock is different, or in other words when having uncorrelated error term and uncorrelated constant which captures the individual characteristics. And while the Fixed Effects model assumes the individual specific effect is correlated with the independent variables, the Random Effects model is more suitable if the error terms are correlated. The Random Effects estimator is appropriate when the unobserved effect is thought to be uncorrelated with all explanatory variables (Wooldridge, 2013). The research applied Hausman test (Hausman, 1978) to decide on which of the two models is more appropriate to fit the data such that if the Hausman test null hypothesis is rejected then the fixed effects model should be used instead of the random effects model.

The fixed Effects model can be represented as:

where

$$
Y_{i t}=\beta_{1} X_{i t}+\alpha_{i}+u_{i t}
$$

$\mathrm{t}=1$ to $\mathrm{T}$, and $\mathrm{i}=1$ to $\mathrm{N}$

$\mathrm{Y}_{\text {it }}$ is the dependent variable observed for stock $\mathrm{i}$ at time $\mathrm{t}$

$X_{i t}$ represents the time variant regressor (the independent variable)

$\beta_{1}$ is the independent variable coefficient

$\alpha_{i}$ is the un-observed time-invariant effect unknown intercept for each stock

$\mathrm{u}_{\mathrm{it}}$ is the error term 
"The key insight is that if the unobserved variable does not change over time, then any changes in the dependent variable must be due to influences other than these fixed characteristics." (Stock \& Watson, 2003).

The Random Effects model can be represented as:

where

$$
Y_{i t}=\beta_{0}+\beta_{1} X_{i t}+w_{i t}+\varepsilon_{i t}
$$

$\mathrm{t}=1$ to $\mathrm{T}$, and $\mathrm{i}=1$ to $\mathrm{N}$

$\mathrm{w}_{\text {it }}$ "between-entity error" is the unobserved effects associated with each individual cross-sectional units with the assumption that $\operatorname{Cov}\left(\mathrm{w}_{\mathrm{it}}, \mathrm{X}_{\mathrm{it}}\right)=0$

$\varepsilon_{i t}$ "within-entity error" represents a random effect element unassociated with any cross-sectional units

Following Hausman test, it was resolved that Random effects model is more appropriate, however, the random effects model was then tested against the OLS pooled model (with robust standard errors) using Breusch and Pagan LM test for Random Effects test (Breusch \& Pagan, 1980) to determine which model of the Random Effects or the OLS pooled model is more appropriate where the null hypothesis states that variances across entities are zero meaning no panel effect, hence if the null hypothesis is not rejected then the OLS is considered more appropriate.

The regression with Driscoll-Kraay (Driscoll \& Kraay, 1998) standard errors for coefficients estimated by pooled OLS was also used to verify the models results. Per Driscoll and Kraay model characteristics, and as emphasized in STATA documentation, the error structure is assumed to be heteroskedastic, auto-correlated up to some lag, and possibly correlated between the groups (panels). Driscoll-Kraay standard errors are robust to very general forms of cross-sectional ("spatial") and temporal dependence when the time dimension becomes large.

The research has applied serial correlation test of the linear panel-data models following the Wooldridge test for serial correlation in panel-data models (Wooldridge, 2002) and following Drukker (2003) who presented simulation evidence that this test has good size and power properties in reasonable sample sizes.

The research also applied heteroskedasticity tests following the built-in function estat hettest in STATA which performs the three versions of the Breusch-Pagan (1979) and Cook-Weisberg (1983) test for Heteroskedasticity.

With some models showing existence of serial correlation or Heteroskedasticity, the researcher decided running the Prais-Winsten panel-data regression analysis to verify the results achieved by each of the OLS (with robust standard errors) and the Driscoll-Kraay models due to the ability of Prais-Winsten model being belonging to the Feasible Generalized Least Squares FGLS methods to transform the original model with autocorrelation into one without autocorrelation hence with making the error term in the model uncorrelated (Wooldridge, 2013).

\section{Results and Their Interpretations}

Analysis of the Relative and Incremental Information Contents:

\section{Hypothesis 1:}

As detailed in section 2.3.2, in order to determine the highest relative information content; each independent variable was individually regressed on the TSR in a simple linear regression model of the form:

$$
T S R_{i t}=b_{0}+b_{1} I V_{i t}+e_{i t}
$$

Where $i$ represents the firm and $t$ represents the fiscal year. Throughout the analysis, it has been found out the Random Effects model was more appropriate than the Fixed Effects Model but then the pooled OLS model was more appropriate than the Random Effects model. The models providing the highest $\mathrm{R}$ squared represent the independent variable with the highest relative information content.

The EVAM along with other value-based performance measures studied being EVA margin and residual income did not provide superior relevant information content. The simple linear regression models of the value-based measures were all statistically insignificant under any of the regression techniques examined; hence the null hypothesis was rejected. Furthermore, the coefficient of the EVAM was unexpectedly negative meaning an inverse relationship with shareholder wealth creation which is contradicting with the theory and with the purpose of EVAM by definition. However this result cannot be considered as a drawback in the EVAM or the value-based measures in general but is considered consistent with the results reported in many companies' financials as revealed by unexpected insignificance of certain traditional accounting measures in explaining the variance in the dependent variable TSR, for example the OPMGN was insignificant with an R-squared virtually equal to nil, while ROS and FCF_MGN provided a statistically significant relationship with TSR however with 
very small $\mathrm{R}$ squared equal to $2.85 \%$ and $1.5 \%$ respectively per their simple linear regression models under all three regression techniques.

However, the BV_D_AS being a traditional accounting ratio provided statistically significant relationship with TSR reporting an $\mathrm{R}$ squared of $9.13 \%$ under all techniques while the highest statistically significant relative information content was provided by the $\mathrm{P} \_\mathrm{B}$ multiple which reported an $\mathrm{R}$ squared of $28.87 \%$ under pooled OLS and Driscoll-Kraay models and $40.41 \%$ under the Prais-Winsten model due to the ability of Prais-Winsten to overcome the serial correlation distortion found in $\mathrm{P}_{-} \mathrm{B}$ simple linear regression model. The relevant information content is summarized in the following chart:

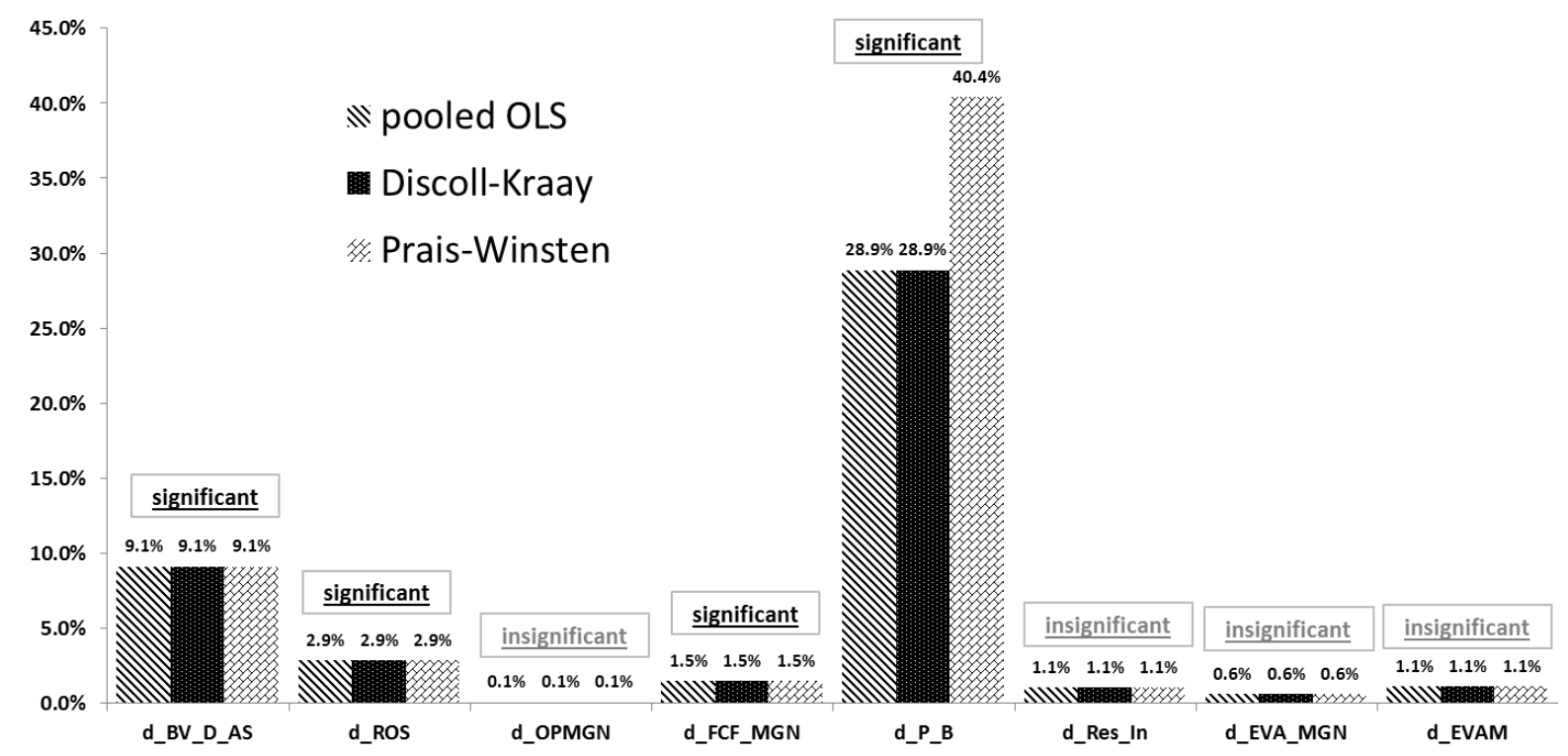

Figure 1. Chart of models R-squared

The above results pointed towards a significant attitude of wide sectors of shareholders aiming at very short-run speculative gains and possibly basing the buy/sell decision on metrics like the price to book value multiple despite other positive or negative factors in the company profile and despite its future business plans, and hence disregarding the company's industry trends in general. This investing attitude could result in destroying shareholders' value and could eventually lead to high negative impact on the market efficiency. It is observed from the above chart that ROS and OPMGN provide very low or no information content in explaining the TSR while $\mathrm{P} \_\mathrm{B}$ is providing an $\mathrm{R}$ squared up to $40 \%$, hence it is considered logical to find the value-based measures offering negligible information content and no statistical significance.

It was observed that many of the companies listed were heavily investing in activities not part of their core businesses as revealed in their financials, it was obvious that many companies' results are affected by abnormal and temporary investment gains or losses which sometimes totally changed the bottom line and contradicted with the real operating profit or EBITDA generated by the company's operations and hence reflecting a totally different picture of the company's earning power from it's core operations. This was also evidenced by lower than expected coefficient of correlation between NP and OPMGN being only 37.7\% pointing out towards significant changes occurring from the OPMGN level until reaching the bottom line. This attitude heavily impacted the balance sheet too in the form of inflated total assets whether financed by equity (book value) or debt and hence inflating the overall cost of capital used to compute the net present value of company sustainable operations or future performances, and accordingly this would work straight against value-based measures like EVA or EVAM and hence suggesting a possible reason on why value-based measures could not be traced or reconciled easily to stock market prices and total shareholder' returns in the UAE market. The fact that some companies' managements may possibly get rewarded based on just net profit or loss may promote such attitude by managements in utilizing the companies' funds into apparently quick rewarding and possibly risky 
investments rather than expanding in the companies' core businesses or spending on the research and development. An incentive and rewarding system based on EVAM could drastically change the companies' management strategies of investment and finance and would positively impact the whole market efficiency.

In addition, many listed companies are in fact conglomerate companies being acquiring significant ownership percentages in different companies and different industries instead of such subsidiaries issuing their own shares in the market which could positively impact the market overall efficiency and liquidity and give the ability to researchers to analyze the industries more efficiently in searching for the implied real value drivers. Another factor is that some companies are owned by strategic investor who would continue to hold the same ownership percentage regardless of any positive or negative changes in the company performances or stock market price. These last two factors contribute to eliminate any unique characteristics of companies and hence it would be considered highly logical to find the fixed effects and random effects models inferior to pooled OLS model where the panel-effect ceases. It may be again requiring an intervention to promote more active trading and issuance of shares rather than holding a static long-term ownership in contrary to the purpose of a public stock market, however this is outside the study scope.

\section{Hypothesis 2:}

Each two independent variables were paired in a multiple linear regression model which resulted in constructing 28 models examined by pooled OLS, Driscoll-Kraay and Prais-Winsten models to find out which independent variable possesses the highest incremental information content per the model:

$$
T S R_{i t}=b_{0}+b_{1} I V 1_{i t}+b_{2} I V 2_{i t}+e_{i t}
$$

Each model outcome generated an $\mathrm{R}$ squared such that each $\mathrm{R}$ squared generated from equation (2) is subtracted from the relevant $\mathrm{R}$ squared resulting from equation (3) to obtain the incremental information content of the variable, for example each of EVAM and ROS produced their individual R squared after being regressed on TSR, then they were paired into a multiple linear regression model to examine their joint explanatory power on TSR, hence reporting a combined $\mathrm{R}$ squared, then by deducting the individual $\mathrm{R}$ squared of EVAM from the combined $\mathrm{R}$ squared it provided the incremental information content of ROS over EVAM.

As found in Appendix 3, neither EVAM nor other value-based performance measures studied being EVA margin and residual income did provide superior incremental information content when paired with other traditional and market-based performance measures; hence the null hypothesis is rejected. The highest incremental information in all the multiple linear regression models arising from pairwise regressions was provided by $\mathrm{P} \_\mathrm{B}$, followed by BV_D_AS, ROS and FCF_MGN, respectively, followed by insignificant explanatory power contributed by OPMGN, Res_In, EVA_MGN or EVAM. This finding is consistent with hypothesis 1 results' and interpretations, and reflects the significant reliability of investors on book value related measures whether in the form of multiples or conventional accounting ratios, followed by small but statistically significant reliability on few accounting measures as ROS or FCF_MGN while company operating results as represented by OPMGN or the value-based measures were statistically insignificant.

\section{Scope Limitation}

This research is prepared over a 6 years sample while excluding insurance companies and Islamic banks, both of which could lead to more insightful results when researched. The scope of the research is focused on the UAE stock market and the researcher recommends undertaking this study on a wider scope in other countries markets in the GCC operating under different macro-economic and taxation regimes and of different levels of efficiency, transparency and development.

The scope of the study did not consider other factors affecting the investor decision making as tax exempt environment, regulatory factors governing speculation and short selling, or a possible simulation if taxes could be levied on short term capital gains.

The scope of the research did not study which component of EVAM is more associated with it's variance.

The scope of the study did not consider the structure or nature of the investors groups or industries and was limited towards focusing on companies' results and overall market movements.

\section{Recommendations for Future Research}

1) Reconsidering this study over bigger sample which could be generated through studying results on quarterly rather than annual basis.

2) Reconsidering this study in the form of comparative research between UAE and other GCC countries while controlling for differences between financial markets efficiency in terms of liquidity, size, level of 
transparency and other factors as tax regimes.

3) Reconsidering this study with introducing macro-economic factors as independent variables for example GDP, commodities prices, interest rates and currency exchange rates movements which could lead to further understanding of the investors profile and preferences in the UAE.

4) Expanding the study further to control for investors' characteristics as local versus foreign investors, or individual versus institutional investors

\section{Summary and Conclusions}

In this study, a through methodology involving statistical tests to ensure data integrity and appropriate data transformation has been followed, in addition panel data regression techniques were deployed, also both relative and incremental information content approaches were employed to investigate whether the EVA Momentum is more associated with shareholders wealth creation in the UAE as compared to peer value-based performance measures and as compared to conventional accounting measures and market-based measures too. The EVAM and so all value-based measures did not provide significant relative or incremental information content while the price to book value multiple provided significant relative information content represented by an $\mathrm{R}$ squared of $40.4 \%$ following the Prais-Winsten regression and an $\mathrm{R}$ squared of $28.9 \%$ under each of the OLS pooled regression and Driscoll-Kraay regression techniques. The price to book value multiple also provided the most superior incremental information content when paired with all metrics. Finally, in this study the total shareholder returns was used as dependent variable, however other variables such as the MVA could be used too as proxy for shareholders wealth creation.

\section{References}

Arabsalehi, M., \& Mahmoodi, I. (2012). The Quest for the Superior Financial Performance Measures. International Journal of Economics and Finance, 4(2), 116-126. http://dx.doi.org/10.5539/ijef.v4n2p116

Aziz, T. (2011). EVAM, A New Revolutionary Ratio? KTH, School of Architecture and the Built Environment (ABE), Real Estate and Construction Management, Banking and Finance (degree of Master), Royal Institute of Technology, Sweden. $\quad$ Retrieved from http://kth.diva-portal.org/smash/get/diva2:503704/FULLTEXT01.pdf

Ben, A. M. R., \& Abaoub, E. (2006). Value Relevance of Accounting Earnings and the Information Content of its Components: Empirical Evidence in Tunisian Stock Exchange (October 2006). http://dx.doi.org/10.2139/ssrn.940791

Biddle, G. C., Bowen, R. M., \& Wallace, J. S. (1997). Does EVA beat earnings? Evidence on associations with stock returns and firm values. Journal of Accounting and Economics, 24(3), 301-336. http://dx.doi.org/10.2139/ssrn.2948

Breusch, T. S., \& Pagan, A. R. (1979). A simple test for heteroscedasticity and random coefficient variation. Econometrica, 47, 1287-1294. Retrieved from http://www.jstor.org/stable/1911963

Breusch, T. S., \& Pagan, A. R. (1980). The Lagrange multiplier test and its applications to model specification in econometrics. Review of Economic Studies, 47, 239-253. Retrieved from http://www.jstor.org/stable/2297111

Collins, D. W., Maydew, E. L., \& Weiss, I. S. (1997). Changes in the value-relevance of earnings and book values over the past forty years. Journal of Accounting \& Economics, 24(1), 39. Retrieved from http://ssrn.com/abstract=2791

Cook, R. D., \& Weisberg, S. (1983). Diagnostics for heteroscedasticity in regression. Biometrika, 70, 1-10. Retrieved from https://biomet.oxfordjournals.org/content/70/1/1.abstract

Dodd, J. L., \& Chen, S. (1997). Economic Value Added (EVA): An Empirical Examination of a New Corporate Performance Measure. Journal of Managerial Issues, (Fall), 318-333. Retrieved from http://www.jstor.org/stable/40604150

Dodd, J. L., \& Chen, S. (2001). Operating Income, Residual Income and EVA: Which Metric Is More Relevant. Journal of Managerial Issues, 13(1), 65-86. Retrieved from http://www.jstor.org/stable/40604334

Driscoll, J. C., \& Aart, C. K. (1998). Consistent Covariance Matrix Estimation with Spatially Dependent Panel Data. Review of Economics and Statistics, 80, 549-560. http://dx.doi.org/10.1162/003465398557825

Drukker, D. M. (2003). Testing for serial correlation in linear panel-data models. Stata Journal, 3(2), 168-177. Retrieved from http://www.stata-journal.com/sjpdf.html?articlenum=st0039 
Esterhuyse, J. C. (2011). Asset turnover as a predictor of shareholder value in the South African manufacturing industry. Retrieved May 1, 2013, from http://hdl.handle.net/10210/7927

Forker, J., \& Powell, R. (2008). A Comparison of Error Rates for EVA, Residual Income, GAAP-Earnings, and Other Metrics Using a Long-Window Valuation Approach. http://dx.doi.org/10.2139/ssrn.1122188

Glezakos, M., Mylonakis, J., \& Kafouros, C. (2012). The Impact of Accounting Information on Stock Prices: Evidence from the Athens Stock Exchange. International Journal of Economics and Finance, 4(2), 56-68. http://dx.doi.org/10.5539/ijef.v4n2p56

Hadri, K. (2000). Testing for stationarity in heterogeneous panel data. Econometrics Journal, 3, 148-161. Retrieved http://www2.warwick.ac.uk/fac/soc/economics/research/workingpapers/2006/twerp_758.pdf

Hausman, J. A. (November 1978). Specification Tests in Econometrics. Econometrica, 46(6), 1251-1271. Retrieved from http://www.jstor.org/stable/1913827

Hogan, C., \& Lewis, C. M. C. (1999). The Long-Run Performance of Firms Adopting Compensation Plans Based on Economic Profits. http://dx.doi.org/10.2139/ssrn.191551

Hogan, C., \& Lewis, C. M. C. (2005). Long-Run Investment Decisions, Operating Performance, and Shareholder Value Creation of Firms Adopting Compensation Plans Based on Economic Profits. Journal of Financial and Quantitative Analysis, 40, 721-746. http://dx.doi.org/10.1017/S0022109000001952

Keener, H. M. (2011). The relative value relevance of earnings and book value across industries. Journal of Accounting \& Economics, 6, 6. Retrieved from http://www.aabri.com/manuscripts/11764.pdf

Kim, W. G. (2006). EVA and Traditional Accounting Measures: Which Metric is a Better Predictor of Market Value of Hospitality Companies? Journal of Hospitality \&amp; Tourism Research, 30, 34. http://dx.doi.org/10.1177/1096348005284268.

Kleiman, Robert of Oakland University. (1999). Some New Evidence on EVA Companies. The Journal of Applied Corporate Finance, 12(2). http://dx.doi.org/10.1111/j.1745-6622.1999.tb00009.x

Levin, A., Lin, C. F., \& Chu, C. S. J. (2002). Unit root tests in panel data: Asymptotic and finite-sample properties. Journal of Econometrics, 108, 1-24. Retrieved from http://www.sciencedirect.com/science/article/pii/S0304-4076(01)00098-7

Maditinos, D. I., Šević, Ž., \& Theriou, N. G. (2009). Performance measures: Traditional accounting measures vs. modern value-based measures. The case of earnings and EVA in the Athens Stock Exchange (ASE). Int. J. Economic Policy in Emerging Economies, 2(4), 323-334. http://dx.doi.org/10.1504/IJEPEE.2009.030935

Mahoney, R. L. (2011). EVA momentum as a performance measure in the United Stated lodging industry (Doctor Of Philosophy Dissertation). ProQuest/UMI Dissertation Publishing, UMI Number 3458300.

Milunovich, S., \& Tsuei, A. (1996). EVA in the Computer Industry. Journal of Applied Corporate Finance, 9 , 104-116. http://dx.doi.org/10.1111/j.1745-6622.1996.tb00108.x

Nakhaei, H., Hamid, N., Anuar, M., \& Nakhaei, K. (2012). Performance Evaluation Using Accounting Variables (Net Profit and Operational Profit) and Economic Measures. International Journal of e-Education, e-Business, e-Management and e-Learning, 2(5). http://dx.doi.org/10.7763/IJEEEE.2012.V2.161

Parvaei, A., \& Farhadi, S. (2013). The Ability of Explaining and Predicting of Economic Value Added (EVA) versus Net Income (NI), Residual Income (RI) \& Free Cash Flow (FCF) in Tehran Stock Exchange (TSE). International Journal of Economics and Finance, 5(2), 67-77. http://dx.doi.org/10.5539/ijef.v5n2p67

Pouraghajan, A., \& Emamgholipourarchi, M. (2012). The Impact of Working Capital Management on Profitability and Market Evaluation: Evidence from Tehran Stock Exchange. International Journal of Business and Social Science, 3(10), 311. Retrieved from http://ijbssnet.com/journals/Vol_3_No_10_Special_Issue_May_2012/33.pdf

Shim, J. K., \& Siegel, J. G. (2008). Financial Management (3rd ed.). Barron's Educational Series, Inc., New York. Library of Congress Catalog Card No. 2007031369.

Stern, J. (2001). The EVA Challenge. New York: John Wiley \& Sons.

Stewart, B. (2003). How to Fix Accounting - Measuring and Reporting Economic Profit. Journal of Applied Corporate Finance, 15(3), 63-82. http://EconPapers.repec.org/RePEc:bla:jacrfn:v:15:y:2003:i:3:p:63-82

Stewart, B. (2009). Eva Momentum: The One Ratio that Tells the Whole Story. Journal of Applied Corporate 
Finance, 21(2), 74-86. http://dx.doi.org/10.1111/j.1745-6622.2009.00228.x

Stock, J. H., \& Watson, M. W. (2006). Introduction to Econometrics. Prentice Hall.

Visaltanachoti, N., Luo, R., \& Yi, Y. (2008). Economic Value Added (EVA®) and Sector Returns. Asian Academy of Management Journal of Accounting and Finance, 4(2), 21-41. Retrieved from http://web.usm.my/journal/aamjaf/vol\%204-2-2008/4-2-2.pdf

Wirawan, D. I. (2011). Effects of EVA (Economic Value Added), EVA Spread, EVA Momentum and Return on Assets ON Stock Return (THESIS, Empirical Study in Indonesian Stock Market). Faculty of Economics and Business Universitas Gadjah Mada.

Wooldridge, J. M. (2001). Econometric Analysis of Cross Section and Panel Data. MIT Press.

Wooldridge, J. M. (2013). Introductory econometrics: A modern approach (5th ed.). Mason, OH, Thomson/South-Western.

Worthington, A. C., \& West, T. (2004). Australian Evidence Concerning the Information Content of Economic Value-Added. Australian Journal of Management, 29(2). Retrieved from http://ssrn.com/abstract=2169811

\section{Appendix 1}

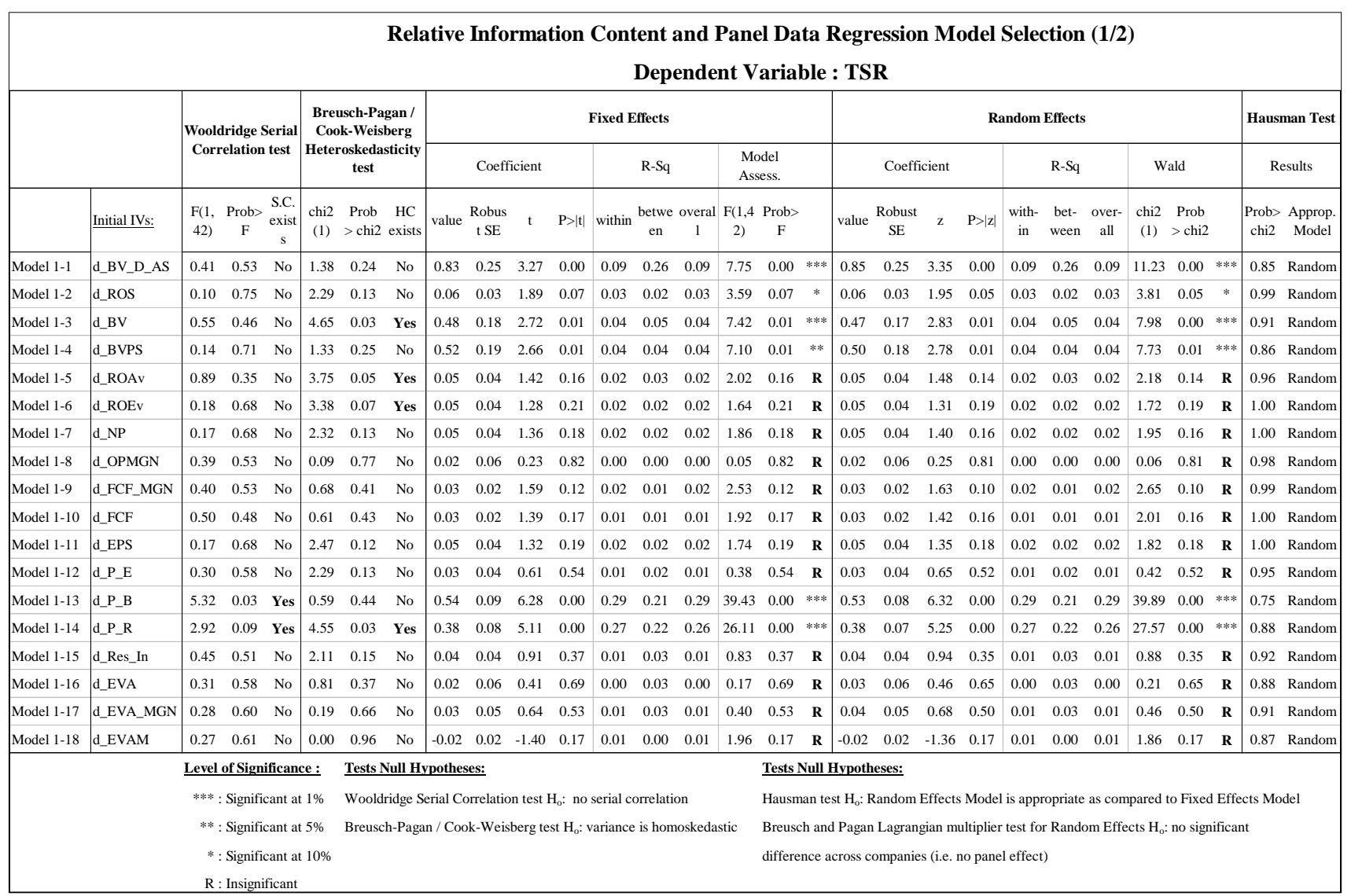


Relative Information Content and Panel Data Regression Model Selection (2/2)

Dependent Variable : TSR

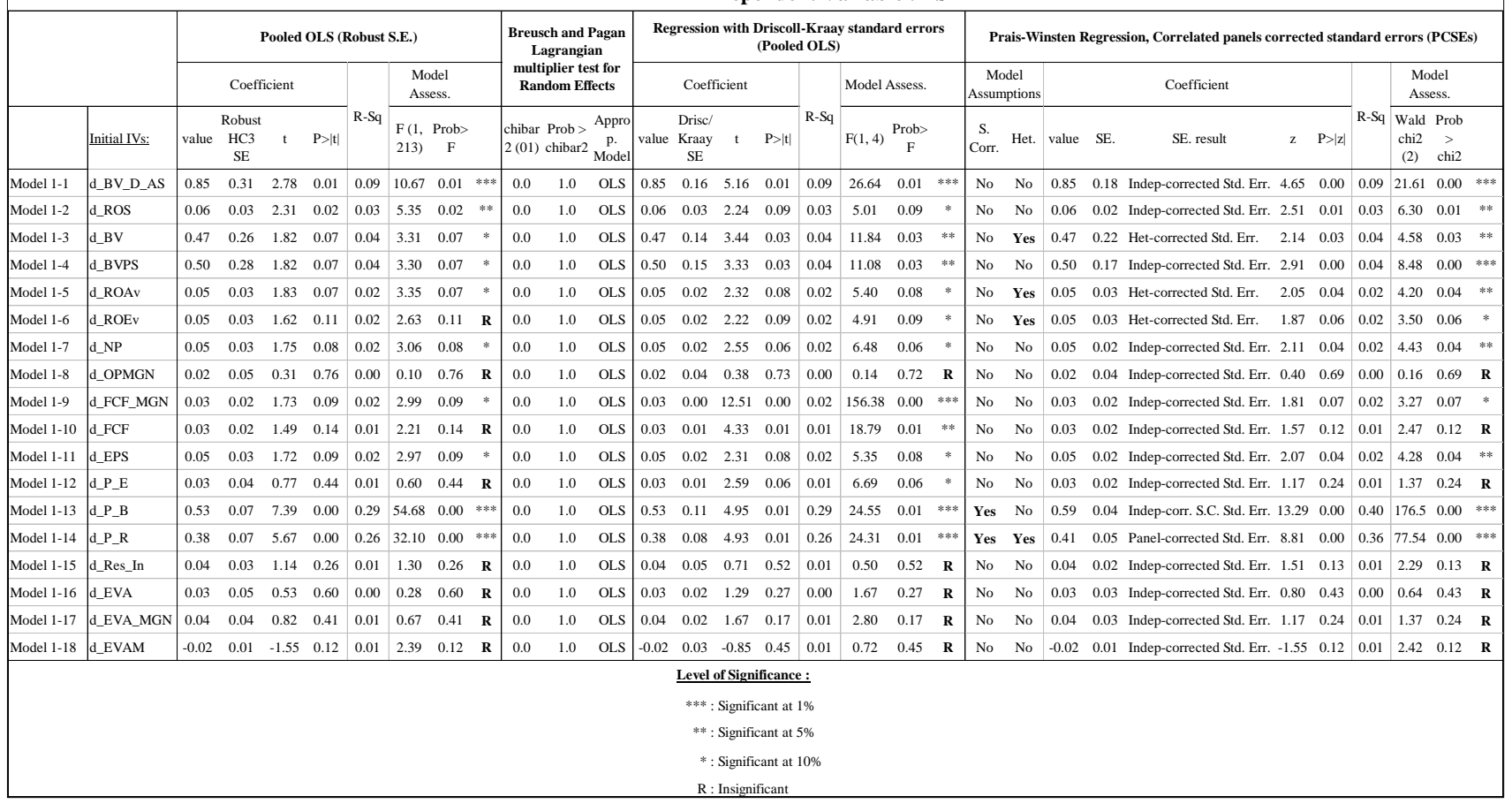

Appendix 2

\begin{tabular}{|c|c|c|c|c|c|c|c|c|c|c|c|c|c|c|c|c|c|c|}
\hline \multicolumn{19}{|c|}{$\begin{array}{l}\text { Multicollinearity Test and Elimination of Independent Variables } \\
\text { Dependent Variable : TSR }\end{array}$} \\
\hline & & \multicolumn{5}{|c|}{ Pooled OLS (Robust S.E.) } & \multicolumn{5}{|c|}{$\begin{array}{l}\text { Driscoll-Kraay standard errors } \\
\text { (Pooled OLS) }\end{array}$} & \multicolumn{5}{|c|}{ Prais-Winsten Regression } & \multirow{3}{*}{$\begin{array}{c}\text { Include in } \\
\text { Final set } \\
\text { of IVs }\end{array}$} & \multirow{3}{*}{ Remarks } \\
\hline & & \multirow{2}{*}{$\begin{array}{l}\text { Coeff- } \\
\text { icient }\end{array}$} & \multirow[b]{2}{*}{ R-Sq } & \multicolumn{3}{|c|}{ Model Assess. } & \multirow{2}{*}{$\begin{array}{l}\text { Coeff- } \\
\text { icient }\end{array}$} & \multirow[b]{2}{*}{ R-Sq } & \multicolumn{3}{|c|}{ Model Assess. } & \multirow{2}{*}{$\begin{array}{c}\text { Coeff- } \\
\text { icient }\end{array}$} & \multirow[b]{2}{*}{ R-Sq } & \multicolumn{3}{|c|}{ Model Assess. } & & \\
\hline & Initial IVs: & & & $\begin{array}{l}F(1, \\
213)\end{array}$ & $\begin{array}{c}\text { Prob> } \\
\text { F }\end{array}$ & & & & $\mathrm{F}(1,4)$ & $\begin{array}{c}\text { Prob> } \\
F\end{array}$ & & & & $\begin{array}{c}\text { Wald } \\
\text { chi2(2) }\end{array}$ & $\begin{array}{c}\text { Prob > } \\
\text { chi2 }\end{array}$ & & & \\
\hline \begin{tabular}{|l|} 
Model 1-1 \\
\end{tabular} & d_BV_D_AS & 0.85 & 0.09 & 7.75 & 0.01 & $* * *$ & 0.85 & 0.09 & 26.64 & 0.01 & $* * *$ & \begin{tabular}{|l|}
0.85 \\
\end{tabular} & 0.09 & 21.61 & 0.00 & **** & YES & significant \\
\hline Model 1-2 & d_ROS & 0.06 & 0.03 & 5.35 & 0.02 & $* *$ & 0.06 & 0.03 & 5.01 & 0.09 & $*$ & \begin{tabular}{|l|}
0.06 \\
\end{tabular} & 0.03 & 6.30 & 0.01 & *** & YES & significant \\
\hline Model 1-3 & d_BV & 0.47 & 0.04 & 3.31 & 0.07 & $*$ & 0.47 & 0.04 & 11.84 & 0.03 & $* *$ & \begin{tabular}{|l|}
0.47 \\
\end{tabular} & 0.04 & 4.58 & 0.03 & ** & No & multicollinear with the superior BV_D_AS \\
\hline Model 1-4 & d_BVPS & 0.50 & 0.04 & 3.30 & 0.07 & * & 0.50 & 0.04 & 11.08 & 0.03 & $* *$ & 0.50 & 0.04 & 8.48 & 0.00 & $* * *$ & No & multicollinear with the superior BV_D_AS \\
\hline Model 1-5 & d_ROAv & 0.05 & 0.02 & 3.35 & 0.07 & $*$ & 0.05 & 0.02 & 5.40 & 0.08 & * & 0.05 & 0.02 & 4.20 & 0.04 & ** & No & multicollinear with the superior ROS \\
\hline Model 1-6 & d_ROEv & 0.05 & 0.02 & 2.63 & 0.11 & $\mathbf{R}$ & 0.05 & 0.02 & 4.91 & 0.09 & $*$ & 0.05 & 0.02 & 3.50 & 0.06 & * & No & multicollinear with the superior ROS \\
\hline Model 1-7 & d_NP & 0.05 & 0.02 & 3.06 & 0.08 & * & 0.05 & 0.02 & 6.48 & 0.06 & * & 0.05 & 0.02 & 4.43 & 0.04 & ** & No & multicollinear with the superior ROS \\
\hline Model 1-8 & d_OPMGN & 0.02 & 0.00 & 0.10 & 0.76 & $\mathbf{R}$ & 0.02 & 0.00 & 0.14 & 0.72 & $\mathbf{R}$ & 0.02 & 0.00 & 0.16 & 0.69 & $\mathbf{R}$ & YES & in-significant \\
\hline Model 1-9 & d_FCF_MGN & 0.03 & 0.02 & 2.99 & 0.09 & $*$ & 0.03 & 0.02 & 156.4 & 0.00 & $* * *$ & 0.03 & 0.02 & 3.27 & 0.07 & $*$ & YES & significant \\
\hline Model 1-10 & d_FCF & 0.03 & 0.01 & 2.21 & 0.14 & $\mathbf{R}$ & 0.03 & 0.01 & 18.79 & 0.01 & $* *$ & 0.03 & 0.01 & 2.47 & 0.12 & $\mathbf{R}$ & No & multicollinear with the superior FCF_MGN \\
\hline Model 1-11 & d_EPS & 0.05 & 0.02 & 2.97 & 0.09 & * & 0.05 & 0.02 & 5.35 & 0.08 & $*$ & 0.05 & 0.02 & 4.28 & 0.04 & $* *$ & No & multicollinear with the superior ROS \\
\hline Model 1-12 & d_P_E & 0.03 & 0.01 & 0.60 & 0.44 & $\mathbf{R}$ & 0.03 & 0.01 & 6.69 & 0.06 & * & 0.03 & 0.01 & 1.37 & 0.24 & $\mathbf{R}$ & No & multicollinear with the superior ROS \\
\hline Model 1-13 & d_P_B & 0.53 & 0.29 & 54.68 & 0.00 & $* * *$ & 0.53 & 0.29 & 24.55 & 0.01 & $* * *$ & 0.59 & 0.40 & 176.5 & 0.00 & $* * *$ & YES & significant \\
\hline Model 1-14 & d_P_R & 0.38 & 0.26 & 32.10 & 0.00 & $* * *$ & 0.38 & 0.26 & 24.31 & 0.01 & $* * *$ & 0.41 & 0.36 & 77.54 & 0.00 & $* * *$ & No & multicollinear with the superior $\mathrm{P}_{-} \mathrm{B}$ \\
\hline Model 1-15 & d_Res_In & 0.04 & 0.01 & 1.30 & 0.26 & $\mathbf{R}$ & 0.04 & 0.01 & 0.50 & 0.52 & $\mathbf{R}$ & 0.04 & 0.01 & 2.29 & 0.13 & $\mathbf{R}$ & YES i & in-significant \\
\hline Model 1-16 & d_EVA & 0.03 & 0.00 & 0.28 & 0.60 & $\mathbf{R}$ & 0.03 & 0.00 & 1.67 & 0.27 & $\mathbf{R}$ & 0.03 & 0.00 & 0.64 & 0.43 & $\mathbf{R}$ & No & multicollinear with the superior EVA_MGN \\
\hline Model 1-17 & d_EVA_MGN & 0.04 & 0.01 & 0.67 & 0.41 & $\mathbf{R}$ & 0.04 & 0.01 & 2.80 & 0.17 & $\mathbf{R}$ & \begin{tabular}{|l|}
0.04 \\
\end{tabular} & 0.01 & 1.37 & 0.24 & $\mathbf{R}$ & YES & in-significant \\
\hline \begin{tabular}{|l|} 
Model 1-18 \\
\end{tabular} & d_EVAM & \begin{tabular}{|l|}
-0.02 \\
\end{tabular} & 0.01 & 2.39 & 0.12 & $\mathbf{R}$ & \begin{tabular}{|l|}
-0.02 \\
\end{tabular} & 0.01 & 0.72 & 0.45 & $\mathbf{R}$ & \begin{tabular}{|l|}
-0.02 \\
\end{tabular} & 0.01 & 2.42 & 0.12 & $\mathbf{R}$ & YES & in-significant \\
\hline & & $\begin{array}{r}\text { Level of } \\
* * * \\
* * \\
*: \\
R:\end{array}$ & $\begin{array}{l}\text { Signific } \\
\text { Signific } \\
\text { Signific } \\
\text { Insignif }\end{array}$ & $\begin{array}{l}\text { icance: } \\
\text { cant at } 1 \% \\
\text { cant at } 5 \% \\
\text { ant at } 10 \\
\text { ficant }\end{array}$ & & & & & & & & & & & & & & \\
\hline
\end{tabular}




\section{Appendix 3}

\begin{tabular}{|c|c|c|c|c|c|c|c|c|c|c|c|c|c|c|c|c|c|c|c|c|c|c|c|c|c|c|c|}
\hline \multicolumn{28}{|c|}{$\begin{array}{l}\text { Incremental Information Content } \\
\text { Dependent Variable : TSR }\end{array}$} \\
\hline & & \multirow{3}{*}{$\begin{array}{c}\text { Pairs } \\
\text { Correl- } \\
\text { ations }\end{array} \mid$} & \multirow{2}{*}{$\begin{array}{c}\text { Wooldridge Serial } \\
\text { Correlation test }\end{array}$} & \multirow{2}{*}{\multicolumn{2}{|c|}{ 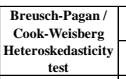 }} & \multicolumn{6}{|c|}{ Pooled OLS (Robust S.E.) } & \multicolumn{7}{|c|}{\begin{tabular}{|c|} 
Regression with Driscoll-Kraay standard errors (Pooled \\
OLS)
\end{tabular}} & \multicolumn{9}{|c|}{$\begin{array}{l}\text { Prais-Winsten Regression, Correlated panels corrected standard errors } \\
(\text { PCSEs })\end{array}$} \\
\hline & & & & & & \multicolumn{3}{|c|}{ Coefficient } & \multirow{2}{*}{\multicolumn{2}{|c|}{\begin{tabular}{|c|}
$\begin{array}{c}\text { Model } \\
\text { Assess. }\end{array}$ \\
$\begin{array}{l}\mathrm{F}(2,2) \\
\text { 12) }\end{array}$ \\
\end{tabular}}} & \multirow{2}{*}{$\begin{array}{c}\text { R-Sq } \\
\text { Increm } \\
\text { ental } \\
\text { Conte } \\
\text { nt }\end{array}$} & \multicolumn{3}{|c|}{ Coefficient } & \multirow[b]{2}{*}{$\mathrm{R}-\mathrm{Sq}$} & \multicolumn{2}{|c|}{\begin{tabular}{|c|} 
Model \\
Assess. \\
\end{tabular}} & \multirow{2}{*}{\begin{tabular}{|c|} 
R-Sq \\
Increm \\
ental \\
Conte \\
nt
\end{tabular}} & \begin{tabular}{|c|} 
Model \\
Assumptions \\
\end{tabular} & \multicolumn{3}{|c|}{ Coefficient } & & \multirow{2}{*}{\multicolumn{2}{|c|}{\begin{tabular}{|c|} 
Model Assess. \\
$\begin{array}{c}\text { Wald } \\
\text { chi2(2 } \\
\text { ) }\end{array} \begin{array}{c}\text { Prob }> \\
\text { chi2 }\end{array}$ \\
\end{tabular}}} & \multirow{2}{*}{\multicolumn{2}{|c|}{\begin{tabular}{|c|} 
R-Sq \\
Increm \\
ental \\
Cont- \\
ent
\end{tabular}}} \\
\hline & & & $\begin{array}{|ccc|}\mathrm{F} & \text { Prob } & \text { S.C. } \\
(1,42) & >\mathrm{F} & \text { exists } \\
\end{array}$ & $\begin{array}{ll}\text { chi2 } & \text { P } \\
(1) & 0\end{array}$ & \begin{tabular}{cc|} 
Prob & HC \\
chi2 & exists
\end{tabular} & & 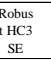 & $P>|x|$ & & & & $\begin{aligned} \mathrm{Dr} \\
\mathrm{Kr} \\
\mathrm{S}\end{aligned}$ & $\begin{array}{l}\text { Srisc/ } \\
\text { Sraay } \\
\text { SE }\end{array}$ & $P>|t|$ & & \begin{tabular}{|rr}
$\mathrm{F}(2$, & Prot \\
$4)$ & $\mathrm{F}$
\end{tabular} & rob & & s.Corr. Het. & value $\begin{array}{cc}\mathrm{cc} \\
\mathrm{c}-\mathrm{y}\end{array}$ & $\begin{array}{l}\text { raller } \\
\text { corre } \\
\text { c-ted }\end{array}$ & $P>\mid$ & $\mathrm{R}-\mathrm{Sq}$ & & & & \\
\hline 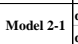 & & 12 & $\begin{array}{lll}0.05 & 0.83 & \text { No }\end{array}$ & $0.03 \quad 0$ & 0.86 № & 20 & $\begin{array}{ll}0.27 & 3 \\
0.02 & 3\end{array}$ & \begin{tabular}{|l|l|}
3.46 & 0.00 \\
3.40 & 0.00
\end{tabular} & 0.13 & $11.18 \quad 0.00 *:$ & \begin{tabular}{|l|}
0.11 \\
0.04
\end{tabular} & $\begin{array}{ll}92 & 0 . \\
08 & 0\end{array}$ & $\begin{array}{ll}0.14 & 6.53 \\
0.01 & 5.15\end{array}$ & & 0.132 & $23.85 \quad 0.0$ & 0.0 & \begin{tabular}{|l|}
0.11 \\
0.04
\end{tabular} & No & $\begin{array}{ll}0.92 & 0 \\
0.08 & 0\end{array}$ & $\begin{array}{ll}0.18 \\
0.18 & 5.1 \\
0.02 & 3.2\end{array}$ & $\begin{array}{ll}5.13 & 0.0 \\
3.28 & 0.0\end{array}$ & 0.000 .13 & $\begin{array}{lll}13 & 33.42 & 0 .\end{array}$ & 0.00 & 0.11 & \\
\hline del 2-2 & & -0.02 & $0.41 \quad 0.53 \quad$ No & 70 & 0.30 No & & $\begin{array}{ll}0.30 & 2 \\
0.04 & 0\end{array}$ & $\begin{array}{ll}2.81 & 0.01 \\
0.43 & 0.67\end{array}$ & 0.09 & $4.22 \quad 0.02 \quad * *$ & & & $\begin{array}{ll}0.16 & 5.28 \\
0.03 & 0.60\end{array}$ & 0.01 & 0.092 & $29.00 \quad 0.0$ & 0.0 & \begin{tabular}{|l|}
0.09 \\
0.00
\end{tabular} & No & $\begin{array}{ll}0.85 & 0 \\
0.02 & 0\end{array}$ & $\begin{array}{ll}0.18 & 4.6 \\
0.04 & 0.5\end{array}$ & $\begin{array}{cc}4.66 & 0.0 \\
0.51 & 0.6\end{array}$ & .00 & $\begin{array}{lll}09 & 21.90 & 0 .\end{array}$ & 0.00 & 00 & \\
\hline 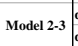 & & \begin{tabular}{|l|}
0.01 \\
\end{tabular} & $0.400 .53 \quad$ No & 0 & 0.52 No & & $\begin{array}{ll}0.31 & 2 \\
0.02 & 1\end{array}$ & $\begin{array}{ll}2.69 & 0.01 \\
1.83 & 0.07\end{array}$ & 0.11 & $4.74 \quad 0.01$ & \begin{tabular}{|l|}
0.09 \\
0.01
\end{tabular} & $\begin{array}{ll}0.85 & 0 \\
0.03 & 0 .\end{array}$ & $\begin{array}{ll}0.20 & 4.31 \\
0.01 & 5.62\end{array}$ & 0.01 & 0.112 & $21.92 \quad 0.0$ & $* *$ & \begin{tabular}{|l|}
0.09 \\
0.01
\end{tabular} & No & $\begin{array}{ll}85 & 0 . \\
03 & 0 .\end{array}$ & $\begin{array}{ll}0.18 & 4.6 \\
0.02 & 1.8\end{array}$ & $\begin{array}{ll}4.67 & 0.0 \\
1.85 & 0.0\end{array}$ & .00 & $\begin{array}{lll}11 & 25.39 & 0 .\end{array}$ & 0.0 & $\begin{array}{l}0.09 \\
0.01\end{array}$ & \\
\hline 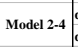 & & -0.14 & $5.98 \quad 0.02 \quad$ Yes & $0.82 \quad 0$ & 0.37 No & & $\begin{array}{cc}0.21 & 5 \\
0.05 & 10\end{array}$ & $\begin{array}{ll}5.26 & 0.00 \\
0.91 & 0.00\end{array}$ & 0.44 & $\begin{array}{lll}70.80 & 0.4\end{array}$ & \begin{tabular}{|l|}
0.15 \\
0.34
\end{tabular} & $\begin{array}{ll}99 \\
58 & 0 .\end{array}$ & $\begin{array}{ll}0.08 & 14.52 \\
0.07 & 8.30\end{array}$ & & 0.441 & 0.0 & 0. & \begin{tabular}{|l|}
0.15 \\
0.34
\end{tabular} & Yes No & $\begin{array}{ll}0.96 & 0 . \\
0.64 & 0\end{array}$ & $\begin{array}{lr}0.11 & 8.5 \\
0.04 & 16 .\end{array}$ & & .000 .55 & \begin{tabular}{l|ll}
55 & 307.1 & 0.
\end{tabular} & 0.00 & 0.15 & \\
\hline lodel 2-5 & & 0.02 & $0.64 \quad 0.43 \quad$ No & $0.44 \quad 0$ & $0.51 \quad$ No & & $\begin{array}{ll}0.30 \\
0.03 & 1 .\end{array}$ & $\begin{array}{ll}2.86 & 0.01 \\
1.15 & 0.25\end{array}$ & 0.10 & $5.14 \quad 0.01$ & $\begin{array}{l}0.09 \\
0.01\end{array}$ & & $\begin{array}{ll}0.17 & 5.02 \\
0.05 & 0.72\end{array}$ & & 0.103 & 30 & $0.00 * * * *$ & 0.01 & No No & & $\begin{array}{lr}0.18 & 4.6 \\
0.02 & 1.4\end{array}$ & & $\begin{array}{ll}.00 & 0.10 \\
0.14 & 0.10\end{array}$ & $\begin{array}{lll}10 & 24.07 & 0 .\end{array}$ & 0.00 & 0.09 & \\
\hline del 2-6 & & $\mid-0.01$ & $\begin{array}{lll}0.33 & 0.57 & \text { No }\end{array}$ & 0 & 0.34 No & & $\begin{array}{ll}0.30 & 2 \\
0.04 & 0 .\end{array}$ & $\begin{array}{ll}2.89 & 0.00 \\
0.95 & 0.34\end{array}$ & 0.10 & \begin{tabular}{lll|}
4.57 & 0.01 & $* *$
\end{tabular} & & & $\begin{array}{ll}0.14 & 5.98 \\
0.01 & 3.73\end{array}$ & $\begin{array}{l}0.00 \\
0.02\end{array}$ & 0.101 & 19.190 .0 & $.01 \quad * * *$ & \begin{tabular}{|l|}
0.09 \\
0.01
\end{tabular} & No $\frac{0}{0}$ & & $\begin{array}{ll}0.18 & 4.6 \\
0.03 & 1.2\end{array}$ & $\begin{array}{ll}4.68 & 0.0 \\
1.29 & 0.2\end{array}$ & \begin{tabular}{l|l}
.00 & 0.10 \\
.20 & 0.10
\end{tabular} & $\begin{array}{lll}10 & 23.44 & 0 .\end{array}$ & 0.0 & 0.09 & \\
\hline 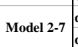 & & 0.04 & $\begin{array}{lll}0.56 & 0.46 & \text { No }\end{array}$ & 1.200 & 0.27 No & & $\begin{array}{ll}0.30 & 2 \\
0.01 & -1\end{array}$ & $\begin{array}{ll}2.85 & 0.01 \\
1.76 & 0.08\end{array}$ & 0.11 & $5.72 \quad 0.00 * * *$ & & & $\begin{array}{ll}0.15 & 5.59 \\
0.02 & -0.99\end{array}$ & $\begin{array}{l}0.01 \\
0.38\end{array}$ & 0.112 & $22.40 \quad 0.0$ & $=$ & \begin{tabular}{|l|}
0.09 \\
0.01
\end{tabular} & No & $\begin{array}{ll}36 & 0 . \\
02 & 0 .\end{array}$ & $\begin{array}{ll}0.18 & 4.7 \\
0.01 & -1.8\end{array}$ & $\begin{array}{ll}4.75 & 0.0 \\
1.81 & 0.0\end{array}$ & \begin{tabular}{l|l}
.00 & 0.11 \\
.07 & 0.11
\end{tabular} & $\begin{array}{lll}11 & 25.21 & 0 .\end{array}$ & 0.00 & 0.01 & \\
\hline el 2-8 & & 35 & $\begin{array}{|lll|}0.16 & 0.69 & \text { No }\end{array}$ & 3.260 & 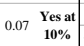 & $\begin{array}{cc}0.07 & 0 \\
-0.02 & 0\end{array}$ & $\begin{array}{cc}0.03 & 2 . \\
0.05 & -0\end{array}$ & $\begin{array}{ll}2.42 & 0.02 \\
0.45 & 0.66\end{array}$ & 0.03 & $2.94 \quad 0.06$ & & & $\begin{array}{ll}0.03 & 2.31 \\
0.03 & -0.71\end{array}$ & \begin{tabular}{|l|}
0.08 \\
0.52
\end{tabular} & 0.032 & $\begin{array}{ll}2.67 & 0.1\end{array}$ & $\mathbf{R}$ & \begin{tabular}{|l|}
0.03 \\
0.00 \\
\end{tabular} & \begin{tabular}{c|c} 
Yes at \\
0 \\
$10 \%$
\end{tabular} & $\begin{array}{cc}0.07 & 0 . \\
-0.02 & 0 .\end{array}$ & $\begin{array}{ll}0.03 & 2.2 \\
0.04 & -0.4\end{array}$ & & $\begin{array}{lll}0.02 & 0.03 \\
.64 & 0.03\end{array}$ & $\begin{array}{lll}03 & 5.34 & 0 .\end{array}$ & 0. & 0.03 & \\
\hline 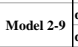 & $d_{d} d_{-} \mathbf{R}$ & 99 & $\begin{array}{lll}0.18 & 0.67 & \text { No }\end{array}$ & 0.590 & 0.44 No & & $\begin{array}{ll}0.03 & 2 . \\
0.02 & 1 .\end{array}$ & $\begin{array}{ll}2.22 & 0.03 \\
1.52 & 0.13\end{array}$ & 0.04 & $\begin{array}{ll}4.32 & 0.01\end{array}$ & \begin{tabular}{|l|}
0.03 \\
0.03
\end{tabular} & $\begin{array}{ll}6 & 0 . \\
13 & 0 .\end{array}$ & $\begin{array}{ll}0.03 & 2.16 \\
0.01 & 4.43\end{array}$ & $\begin{array}{l}0.10 \\
0.01\end{array}$ & 0.042 & $\begin{array}{lll}243.3 & 0.0\end{array}$ & 0.0 & \begin{tabular}{|l|}
0.03 \\
0.01 \\
\end{tabular} & No & $\begin{array}{ll}0.06 & 0 . \\
0.03 & 0 .\end{array}$ & $\begin{array}{ll}0.02 & 2.3 \\
0.02 & 1.6\end{array}$ & & $\begin{array}{lll}0.02 & 0.04 \\
0.11 & 0.04\end{array}$ & $\begin{array}{lll}04 & 8.98 & 0 .\end{array}$ & 0.01 & $\begin{array}{l}.03 \\
.01\end{array}$ & \\
\hline & $\frac{d-R}{d-P}$ & 0.22 & $\begin{array}{lll}5.18 & 0.03 & \text { Yes }\end{array}$ & 0.600 & 0.44 № & $\begin{array}{ll}0.02 & 0 \\
0.52 & 0\end{array}$ & $\begin{array}{ll}0.03 & 0 \\
0.07 & 7\end{array}$ & $\begin{array}{ll}0.64 & 0.53 \\
7.22 & 0.00\end{array}$ & 0.29 & $26.06 \quad 0.00$ & \begin{tabular}{|l|}
0.00 \\
0.26
\end{tabular} & $\begin{array}{ll}2 & 0\end{array}$ & $\begin{array}{ll}0.03 & 0.74 \\
0.10 & 5.16\end{array}$ & $\begin{array}{l}0.50 \\
0.01 \\
\end{array}$ & 0.291 & 0.0 & 0.0 & 26 & Yes & $\begin{array}{lll}3 & 0 . \\
7 & 0 .\end{array}$ & $\begin{array}{ll}0.02 & 1.5 \\
0.05 & 12.4\end{array}$ & $\begin{array}{lll}1.54 & 0.1 \\
2.47 & 0.0\end{array}$ & $\frac{12}{0.12} 0.41$ & $\begin{array}{lll}41 & 179.7 & 0 .\end{array}$ & 0.0 & 00 & \\
\hline 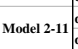 & & 0.17 & $0.20 \quad 0.66 \quad$ No & 3.500 & $\begin{array}{cc}0.06 & \begin{array}{l}\text { Yes at } \\
10 \%\end{array}\end{array}$ & $\begin{array}{ll}0.06 & 0 \\
0.03 & 0\end{array}$ & $\begin{array}{ll}0.03 & 2 \\
0.03 & 0 .\end{array}$ & $\begin{array}{ll}2.11 & 0.04 \\
0.87 & 0.39\end{array}$ & 0.03 & $2.79 \quad 0.0$ & & & $\begin{array}{ll}0.03 & 1.86 \\
0.05 & 0.51\end{array}$ & $\begin{array}{l}0.14 \\
0.64 \\
\end{array}$ & 0.032 & 2.70 & $\mathbf{R}$ & 01 & to $\begin{array}{c}\text { Yes at } \\
10 \%\end{array}$ & $\begin{array}{ll}0.06 & 0 . \\
0.03 & 0 .\end{array}$ & $\begin{array}{ll}0.03 & 2.1 \\
0.03 & 1.0\end{array}$ & $\begin{array}{ll}2.10 & 0 \\
1.00 & 0\end{array}$ & $\begin{array}{ll}32 & 0.03\end{array}$ & \begin{tabular}{l|ll}
03 & 5.44 & 0.
\end{tabular} & 0.07 & 02 & \\
\hline & & 0.01 & $\begin{array}{lll}0.08 & 0.78 & \text { No }\end{array}$ & 0 & 0.34 No & $\begin{array}{ll}0.06 & 0 \\
0.04 & 0\end{array}$ & $\begin{array}{ll}0.03 & 2 . \\
0.04 & 0\end{array}$ & $\begin{array}{ll}2.22 & 0.03 \\
0.81 & 0.42\end{array}$ & 0.03 & $\begin{array}{ll}2.57 & 0.08\end{array}$ & & & $\begin{array}{ll}0.03 & 2.20 \\
0.02 & 1.50\end{array}$ & $\begin{array}{l}0.09 \\
0.21\end{array}$ & 0.032 & 2.65 & $\mathbf{R}$ & \begin{tabular}{|l|}
0.03 \\
0.01
\end{tabular} & 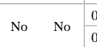 & $\begin{array}{ll}0.06 & 0 . \\
0.04 & 0 .\end{array}$ & $\begin{array}{ll}0.02 & 2.5 \\
0.03 & 1.1\end{array}$ & $\begin{array}{ll}2.50 & 0.0 \\
1.15 & 0.2\end{array}$ & \begin{tabular}{l|l}
.01 & 0.03 \\
.25 & 0.03
\end{tabular} & $\begin{array}{lll}03 & 7.66 & 0 .\end{array}$ & 0.02 & $\begin{array}{l}0.03 \\
0.01\end{array}$ & \\
\hline & $\begin{array}{l}\text { d_ROS } \\
\text { d_EVEAM }\end{array}$ & 3 & No & & 0.13 & & $\begin{array}{ll}0.03 & 2 \\
0.01 & -1\end{array}$ & $\begin{array}{ll}2.09 & 0.04 \\
1.24 & 0.22\end{array}$ & 0.04 & $\begin{array}{ll}3.78 & 0.02\end{array}$ & & & $\begin{array}{ll}0.03 & 2.12 \\
0.02 & -0.74\end{array}$ & $\begin{array}{l}0.10 \\
4.50\end{array}$ & 0.042 & 2.4 & $\mathbf{R}$ & 11 & -6 & $\begin{array}{cc}0.06 & 0 . \\
-0.02 & 0 .\end{array}$ & $\begin{array}{ll}0.02 & 2.3 \\
0.01 & -1.2\end{array}$ & $\begin{array}{ll}2.33 & 0.0 \\
1.25 & 0.2\end{array}$ & $\begin{array}{lll}0.02 & 0.04 \\
.21 & 0.04\end{array}$ & 0. & 0.0 & $\begin{array}{l}0.02 \\
0.01\end{array}$ & \\
\hline & & 13 & $\begin{array}{lll}0.53 & 0.47 & \text { No }\end{array}$ & 0.730 & 0.39 No & & & $\begin{array}{ll}0.27 & 0.79 \\
1.72 & 0.09\end{array}$ & 0.02 & $\begin{array}{lll}1.50 & 0.23 & \mathbf{R}\end{array}$ & & & $\begin{array}{ll}0.04 & 0.33 \\
0.00 & 10.91\end{array}$ & & 0.021 & $107.6 \quad 0.0$ & 0.00 & 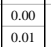 & 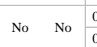 & $\begin{array}{ll}0.01 & 0 . \\
0.03 & 0 .\end{array}$ & & $\begin{array}{ll}0.36 & 0.7 \\
1.80 & 0.0\end{array}$ & $\begin{array}{lll}.72 & 0.02 \\
.07 & 0.02\end{array}$ & $\begin{array}{lll}02 & 3.40 & 0 .\end{array}$ & 0.18 & .00 & \\
\hline & $\frac{d}{d}-0$ & 0.12 & $4.32 \quad 0.04$ Yes & 1.040 & $0.31 \quad$ No & & $\begin{array}{ll}0.06 & -0 \\
0.07 & 7 .\end{array}$ & $\begin{array}{ll}0.37 & 0.71 \\
7.38 & 0.00\end{array}$ & 0.29 & $\begin{array}{ll}27.50 & 0.00\end{array}$ & \begin{tabular}{|l|l|}
0.29 \\
\end{tabular} & & & & 0.299 & 99.59 & .0 & & ies & & $\begin{array}{ll}0.03 & 1.2 \\
0.04 & 13.1\end{array}$ & $\begin{array}{ll}1.29 & 0 . \\
3.13 & 0 .\end{array}$ & $\begin{array}{ll}20 & 0.41 \\
00 & 0.45\end{array}$ & $\begin{array}{lll}41 & 178.4 & 0 .\end{array}$ & 0.0 & 0 & \\
\hline & & 0.03 & $\begin{array}{lll}0.55 & 0.46 & \text { No }\end{array}$ & 1.480 & $0.22 \mathrm{No}$ & $\begin{array}{lll}1 & 0 \\
4 & 0\end{array}$ & $\begin{array}{ll}0.05 & 0 \\
0.03 & 1 .\end{array}$ & $\begin{array}{ll}0.28 & 0.78 \\
1.12 & 0.26\end{array}$ & 0.01 & $\begin{array}{lll}0.67 & 0.51 & \mathbf{R}\end{array}$ & ${ }_{0}$ & $0.01 \quad 0$. & $\begin{array}{ll}0.04 & 0.31 \\
0.05 & 0.69\end{array}$ & $\begin{array}{l}0.77 \\
0.53\end{array}$ & 0.012 & 2.21 & $\mathbf{R}$ & 0.01 & No & $\begin{array}{l}1 \\
+ \\
+1 .\end{array}$ & $\begin{array}{ll}0.04 & 0.3 \\
0.02 & 1.5\end{array}$ & $\begin{array}{ll}0.35 & 0.7 \\
1.50 & 0.1\end{array}$ & $\begin{array}{lll}.73 & 0.01\end{array}$ & $\begin{array}{lll}01 & 2.41 & 0 .\end{array}$ & 0.30 & .01 & \\
\hline & & & 0.36 & & 0.72 & $\begin{array}{ll}0.02 & 0 \\
0.04 & 0\end{array}$ & $\begin{array}{ll}0.05 & 0 \\
0.04 & 0\end{array}$ & $\begin{array}{ll}0.37 & 0.71 \\
0.85 & 0.40\end{array}$ & 0.01 & $0.46 \quad 0.63$ & 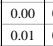 & & $\begin{array}{ll}0.04 & 0.44 \\
0.02 & 1.59\end{array}$ & $\begin{array}{l}0.69 \\
0.19\end{array}$ & 0.011 & 1.4 & $\mathbf{R}$ & 31 & 0 & $\begin{array}{ll}0.02 & 0 . \\
0.04 & 0 .\end{array}$ & $\begin{array}{ll}0.04 & 0.4 \\
0.03 & 1.2\end{array}$ & $\begin{array}{ll}0.49 & 0 . \\
1.21 & 0 .\end{array}$ & $\begin{array}{ll}62 & 0.01 \\
23 & 0.01\end{array}$ & $\begin{array}{lll}01 & 1.61 & 0 .\end{array}$ & 0.45 & .00 & \\
\hline 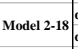 & & -0.14 & $0.42 \quad 0$. & 0 & 0.96 & & $\begin{array}{cc}0.05 & 0 \\
0.01 & -1\end{array}$ & $\begin{array}{ll}0.15 & 0.88 \\
1.48 & 0.14\end{array}$ & 0.01 & $\begin{array}{lll}1.20 & 0.30 & \mathbf{R}\end{array}$ & & $\begin{array}{cc}0.01 & 0 . \\
-0.02 & 0 .\end{array}$ & $\begin{array}{ll}0.03 & 0.25 \\
0.02 & -0.88\end{array}$ & \begin{tabular}{|l|} 
\\
3.81 \\
\end{tabular} & 0.010 & $\begin{array}{ll}0.89 & 0.4\end{array}$ & $\mathbf{R}$ & \begin{tabular}{|l|}
0.00 \\
0.01
\end{tabular} & No & $\begin{array}{lll}1 & 0 . \\
2 & 0 .\end{array}$ & $\begin{array}{cc}0.04 & 0.1 \\
0.01 & -1.5\end{array}$ & $\begin{array}{ll}0.19 & 0.8 \\
1.51 & 0.1\end{array}$ & \begin{tabular}{l|l}
.85 & 0.01 \\
.13 & 0.01
\end{tabular} & $\begin{array}{lll}01 & 2.45 & 0 .\end{array}$ & 0.29 & 00 & \\
\hline & d_E & 0 & $5.30 \quad 0.03$ Yes & 0 & 0.56 No & & $\begin{array}{ll}0.01 & 2 \\
0.07 & 7\end{array}$ & $\begin{array}{ll}2.12 & 0.04 \\
7.57 & 0.00\end{array}$ & 0.30 & $34.95 \quad 0.00 \quad *$ & & & $\begin{array}{ll}0.01 & 3.50 \\
0.10 & 5.21\end{array}$ & & 0.301 & $\begin{array}{ll}108.1 & 0.0\end{array}$ & .00 & & es & & & $\begin{array}{ll}1.61 & 0.1 \\
3.24 & 0.00\end{array}$ & $.00^{0.41}$ & $\begin{array}{lll}41 & 180.2 & 0 .\end{array}$ & 0.00 & 40 & \\
\hline & & 05 & $\begin{array}{lll}0.63 & 0.43 & \text { No }\end{array}$ & $0.00 \quad 0$ & 0.97 & & $\begin{array}{ll}0.02 & 1 \\
0.03 & 1\end{array}$ & $\begin{array}{ll}1.88 & 0.06 \\
1.27 & 0.20\end{array}$ & 0.03 & $\begin{array}{ll}2.69 & 0.07\end{array}$ & & & 18 & & 0.036 & 63.83 & .0 & & No & & & & 0.03 & \begin{tabular}{l|ll}
03 & 5.95 & 0.
\end{tabular} & 0.05 & & \\
\hline & & -0.05 & $\begin{array}{lll}0.33 & 0.57 & \text { No }\end{array}$ & & 0.68 & $\begin{array}{r}30 \\
+\quad 0\end{array}$ & $\begin{array}{ll}0.02 & 1 \\
0.04 & 0\end{array}$ & $\begin{array}{ll}1.77 & 0.08 \\
0.90 & 0.37\end{array}$ & 0.02 & $\begin{array}{ll}1.77 & 0.17\end{array}$ & & $\begin{array}{ll}3 & 0 . \\
4 & 0 .\end{array}$ & $\begin{array}{ll}0.00 & 10.23 \\
0.02 & 2.09\end{array}$ & \begin{tabular}{|l|}
3 \\
0.00 \\
0.11
\end{tabular} & 0.021 & 14 & $* *$ & 0.02 & No & $\begin{array}{ll}30 . \\
+\quad 0 .\end{array}$ & $\begin{array}{l}1.8 \\
1.2\end{array}$ & 1.88 & $\begin{array}{ll}6 & 6.02 \\
20 & 0.02\end{array}$ & $\begin{array}{lll}02 & 4.93 & 0 .\end{array}$ & 0. & .02 & \\
\hline & $\frac{d \_F}{d \_-E}$ & & 0 & & 0.6 & & $\begin{array}{ll}0.02 & 1 \\
0.01 & -1\end{array}$ & $\begin{array}{ll}1.84 & 0.07 \\
1.69 & 0.09\end{array}$ & r & 2 & & & $\begin{array}{ll}0.00 & 13.98 \\
0.03 & -0.95\end{array}$ & $\begin{array}{ll}8.00 \\
5 & 0.39\end{array}$ & \begin{tabular}{|l|l|}
0.03 & 98 \\
\end{tabular} & 9 & 0.0 & \begin{tabular}{|l}
0 \\
0
\end{tabular} & & $\begin{array}{lll}3 & 0.6 \\
2 & 0.6\end{array}$ & $\begin{array}{ll}0.02 & 1.9 \\
0.01 & -1.7\end{array}$ & $\begin{array}{ll}1.95 & 0 \\
1.71 & 0\end{array}$ & 0903 & $\begin{array}{lll}03 & 6.24 & 0 .\end{array}$ & 0.0 & $0 z$ & \\
\hline & & \begin{tabular}{|l|}
0.14 \\
\end{tabular} & $5.30 \quad 0.03$ Yes & 0.470 & 0.49 No & & $\begin{array}{ll}0.07 & 7 \\
0.03 & 0\end{array}$ & $\begin{array}{ll}7.23 & 0.00 \\
0.29 & 0.77\end{array}$ & 0.29 & $26.89 \quad 0.00^{* * * *}$ & & \begin{tabular}{|cc}
0.52 & 0. \\
0.01 & 0.
\end{tabular} & $\begin{array}{ll}0.12 & 4.26 \\
0.06 & 0.17\end{array}$ & $\begin{array}{l}0.01 \\
0.87\end{array}$ & 2923 & 0.0 & **** & \begin{tabular}{|l|}
0.28 \\
0.00 \\
\end{tabular} & 0 & $\begin{array}{ll}0.59 & 0.6 \\
0.03 & 0.6\end{array}$ & $\begin{array}{ll}0.04 & 13.2 \\
0.02 & 1.6\end{array}$ & $\begin{array}{ll}3.24 & 0.00 \\
1.60 & 0.1\end{array}$ & $\begin{array}{lll}0.00 & 0.41 \\
.11 & 0.41\end{array}$ & $\begin{array}{lll}41 & 181.2 & 0 .\end{array}$ & 0.00 & .0. & \\
\hline & & & $\begin{array}{|lll|}5.87 & 0.02 & \text { Yes }\end{array}$ & 0. & 0.70 No & & $\begin{array}{ll}0.07 & 7 . \\
0.04 & -0\end{array}$ & $\begin{array}{ll}7.82 & 0.00 \\
0.73 & 0.47\end{array}$ & 0.29 & 31 & & & $\begin{array}{ll}0.11 & 4.84 \\
0.02 & -1.18\end{array}$ & & 291 & 0.0 & .02 & & 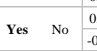 & & $\begin{array}{ll}0.05 & 13.0 \\
0.02 & -0.7\end{array}$ & $\begin{array}{ll}3.06 & 0.0 \\
0.77 & 0.4\end{array}$ & \begin{tabular}{l|l}
.00 & 0.40
\end{tabular} & \begin{tabular}{l|ll}
40 & 177.9 & 0.
\end{tabular} & 0.00 & .00 & \\
\hline & & -0.09 & $\left|\begin{array}{lll}5.07 & 0.03 & \text { Yes }\end{array}\right|$ & 0.180 & 0.67 No & & $\begin{array}{cc}0.07 & 7 \\
0.01 & -1\end{array}$ & $\begin{array}{ll}7.20 & 0.00 \\
1.01 & 0.32\end{array}$ & 0.29 & $27.80 \quad 0.00$ & & & 20 & $\begin{array}{l}0.01 \\
0.48\end{array}$ & $\begin{array}{ll}0.29 & 2 \\
\end{array}$ & 0.0 & .01 & & Yes & & $\begin{array}{ll}0.04 & 13.1 \\
0.01 & -0.9\end{array}$ & $\begin{array}{ll}3.18 & 0.00 \\
0.99 & 0.3\end{array}$ & 1.00 & $\begin{array}{lll}40 & 176.4 & 0 .\end{array}$ & 0.00 & & \\
\hline & $\begin{array}{l}\text { d_Res } \\
\text { d_EV }\end{array}$ & & $0.42 \quad 0.52$ & 2. & $\begin{array}{cc}0.10 & \begin{array}{c}\text { Yes at } \\
10 \%\end{array}\end{array}$ & $\begin{array}{ll}0.04 & 0 \\
0.03 & 0\end{array}$ & $\begin{array}{ll}0.03 & 1 \\
0.05 & 0\end{array}$ & $\begin{array}{ll}1.03 & 0.31 \\
0.73 & 0.47\end{array}$ & 0.02 & $\begin{array}{lll}0.67 & 0.51 & \mathbf{R}\end{array}$ & & $\begin{array}{ll}4 & 0 . \\
13 & 0 .\end{array}$ & $\begin{array}{ll}0.53 & 0.67 \\
0.23 & 1.47\end{array}$ & $\begin{array}{l}0.54 \\
0.22\end{array}$ & $\begin{array}{ll}0.02 & 1\end{array}$ & 1 & $\mathbf{R}$ & 01 & \begin{tabular}{c|c} 
Yes at & 0 \\
$10 \%$ & 0
\end{tabular} & $\begin{array}{ll}0.04 & 0.6 \\
0.03 & 0.6\end{array}$ & $\begin{array}{ll}0.03 & 1.2 \\
0.04 & 0.9\end{array}$ & $\begin{array}{ll}1.21 & 0.22 \\
0.95 & 0.3\end{array}$ & $\begin{array}{lll}0.22 & 0.02 \\
.34 & 0.02\end{array}$ & $\begin{array}{lll}02 & 2.33 & 0 .\end{array}$ & 0.31 & .01 & \\
\hline & & 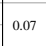 & $\begin{array}{lll}0.41 & 0.53 & \text { No }\end{array}$ & 0 & 0.22 & $\begin{array}{cc}0.04 & 0 \\
-0.02 & 0\end{array}$ & $\begin{array}{ll}0.03 & 1 \\
0.01 & -1\end{array}$ & $\begin{array}{ll}1.22 & 0.22 \\
1.62 & 0.11\end{array}$ & 0.02 & $\begin{array}{lll}2.03 & 0.13 & \mathbf{R}\end{array}$ & 0. & $\begin{array}{ll}04 & 0 . \\
02 & 0 .\end{array}$ & $\begin{array}{cc}0.05 & 0.86 \\
0.03 & -0.87\end{array}$ & 14 & 129 & $\begin{array}{ll}9.77 & 0.0\end{array}$ & $*$ & \begin{tabular}{|l|}
0.01 \\
0.01 \\
\end{tabular} & No & $\begin{array}{ll}4 & 0.0 \\
2 & 0.0\end{array}$ & $\begin{array}{ll}0.02 & 1.6 \\
0.01 & -1.6\end{array}$ & $\begin{array}{ll}1.63 & 0.11 \\
1.67 & 0.11\end{array}$ & $\begin{array}{lll}1.10 & 0.02\end{array}$ & $\begin{array}{lll}02 & 5.10 & 0 .\end{array}$ & 0.08 & 01 & \\
\hline $12-28$ & $\frac{d-E}{d-E}$ & 0. & $\begin{array}{lll}5 & 0.62 & \text { No }\end{array}$ & & No & $\begin{array}{cc}0.04 & 0 \\
-0.02 & 0\end{array}$ & $\begin{array}{cc}0.05 & 0 \\
0.01 & -1\end{array}$ & $\begin{array}{ll}0.84 & 0.40 \\
1.61 & 0.11\end{array}$ & 0.02 & $\begin{array}{lll}1.89 & 0.15 & \mathbf{R}\end{array}$ & & $\begin{array}{cc}0.04 & 0 . \\
-0.02 & 0 .\end{array}$ & $0.03-0$ & $\begin{array}{l}0.21 \\
30.45\end{array}$ & & 0.4 & & & & $\begin{array}{cc}0.04 & 0.6 \\
-0.02 & 0.6\end{array}$ & $\begin{array}{ll}0.03 & 1.2 \\
0.01 & -1.6\end{array}$ & $\begin{array}{ll}1.23 & 0.22 \\
1.60 & 0.1\end{array}$ & $\begin{array}{ll}0.22 & 0.02\end{array}$ & $\begin{array}{lll}02 & 3.95 & 0 .\end{array}$ & & & \\
\hline & & & ignificant & & & & & $H_{a}$ & & stic (ic & & & $*$ & & & & & & & & & & & & & & \\
\hline
\end{tabular}

\section{Copyrights}

Copyright for this article is retained by the author(s), with first publication rights granted to the journal.

This is an open-access article distributed under the terms and conditions of the Creative Commons Attribution license (http://creativecommons.org/licenses/by/3.0/). 